\title{
MODEL NAFKAH DAN PEMENUHAN KEBUTUHAN PANGAN KELUARGA PETANI MISKIN DI HUTAN JATI (Kasus : Enam Desa Di Kabupaten Blora)
}

\author{
Livelihood Source of Poor Farmers in Teak Forests and Food Fulfillment \\ (Case: Six Villages in Blora District) \\ Wasito, Ujang Sumarwan', E. Eko Ananto, Euis Sunarti' ${ }^{1}$, dan/and Arya H. Dharmawan ${ }^{2}$ \\ Balai Besar Pengkajian dan Pengembangan Teknologi Pertanian \\ Jl. Tentara Pelajar 10 Bogor 16114, tlp. (0251) 8351277, Email : wasito63@yahoo.co.id \\ ${ }^{1}$ Departemen Ilmu Keluarga dan Konsumen, Fakultas Ekologi Manusia (FEMA) \\ ${ }^{2}$ Departemen Sains Komunikasi dan Pengembangan Masyarakat, FEMA \\ ${ }^{1 \cdot 2}$ Gd. FEMA, Institut Pertanian Bogor, Jl. Lingkar Akademik, Kampus IPB Dramaga
}

Naskah masuk : 21 April 2010.; Naskah diterima : 25 Maret 2011

\begin{abstract}
This study was conducted to determine of teak forests potency as a source of livelihood for poor farmers in food fulfillment. Primary data was collected in cross-sectional that initiated by naturally observation, focus group discussions, and indepth interviews with respondents in subdistrict and village levels, namely : villages of Bodeh and Ngeliron (Randublatung Subdistrict), Sumberejo and Ngiyono (Japah Subdistrict), Bleboh and Nglebur (Jiken Subdistrict) in 2007 and 2008 period. Two interconnected analysis was emploved to asses : (1) livelihood of poor farmers, and (2) food insecurity index. Valuetion of dimensions, indicators, subindivator weights as well was done by researcher and expert through discussions, and scores were based on the agreement between by researcher and respondents. The results showed that mutualism symbiotic livelihood of poor farmers in the teak forest land based on the fulfillment of food were not optimum yet as indicated by ratio of livelihood source from teak forests and the captured benefit. Poor farmers only captured the small portion of benefit from parasitism symbiotic activities as forest administrator, compared with that of brokers. Livelihood mobility in teak forests was high, it cross could be village, and even subdistrict. Food diversification for poor farmers happened in line with high surplus, very resistant and resistant food for villages. These are based composite index as well as the index of availability, access, utilization, and the vulnerability offood.
\end{abstract}

Keywords: Blora, teakforests, livelihood, poor farmers

\begin{abstract}
ABSTRAK
Untuk mengetahui potensi hutan jati di Kabupaten Blora sebagai sumber nafkah keluarga petani miskin guna memenuhi kebutuhan pangan, telah dilakukan pengkajian data primer secara cross-sectional, diawali dengan pengamatan partisipatif secara alami, diskusi kelompok terfokus, dan wawancara mendalam, pada responden di tingkat kecamatan dan desa, pada selang waktu 2007 dan 2008, di Desa Bodeh dan Ngeliron (Kecamatan Randublatung), Sumberejo dan Ngiyono (Kecamatan Japah), Bleboh dan Nglebur (Kecamatan Jiken). Kajian menggunakan dua analisis yang saling terkait, meliputi : (1) nafkah keluarga petani miskin, dan (2) analisis kerawanan pangan. Penilaian dimensi, indikator, subindikator, bobot dilakukan antara peneliti dengan pakar, sedangkan skor kesepakatan peneliti dengan responden. Hasil kajian, nafkah simbiosis mutualisme keluarga petani miskin di lahan hutan jati berdasarkan pemenuhan pangan belum optimal, karena rasio sumber nafkah lebih kecil dibandingkan pemanfaatannya. Petani miskin hanya menikmati keuntungan sangat kecil dari nafkah simbiosis parasitisme, sedangkan sebagian besar dinikmati oleh pedagang perantara. Mobilitas nafkah di hutan jati tinggi, bisa lintas desa, dan kecamatan. Diversifikasi pangan keluarga petani miskin selaras dengan analisis desa yang surplus tinggi, sangat tahan dan tahan pangan, berdasarkan indeks komposit kerawanan pangan (ketersediaan, akses, pemanfaatan, dan kerentanan pangan).
\end{abstract}

Kata kunci : Blora, hutan jati, nafkah, petani miskin 


\section{PENDAHULUAN}

Luas hutan jati di Kabupaten Blora cukup dominan, yaitu 90.416, 52 ha $(49,52 \%)$. Perum Perhutani sebagai pengelola hutan jati dan memiliki kantor di Kabupaten Blora, meliputi Kesatuan Pemangkuan Hutan (KPH) Cepu, Randublatung, dan Blora, sebagian lagi berada di KPH Ngawi, Mantingan, dan Kebonharjo. Produksi kayu jati $(\mathrm{m} 3)$ yang masih dominan selaras luas kelas hutan produktif (ha), berada di Kecamatan Jiken $(22.786,2 \mathrm{~m} 3 ; 13.445,4$ ha), Sambong (7.835,8 m3; 5.899 ha), Jepon (1.539,3 m3; 4.643,9 ha) di KPH Cepu; Kecamatan Jati (22.526 m3; 13.195,8 ha), Randublatung (11.983 m3; 13.869,2 ha), Kunduran (2.385 m3; 3.738,6 ha) di KPH Randublatung; Kecamatan Japah (3.364 m3; 5.559 ha), Todanan (2.349 m3; 5.223,5 ha), Banjarejo (1.747 m3; 4.061,4 ha) di KPH Blora (BPS dan Bappeda Blora, 2008) dari 16 kecamatan di Kabupaten Blora. Luasan hutan jati tersebut bersinergi dengan persentasi keluarga miskin, masing-masing yaitu 36,71\%; 46,02\%; 35,65\% (KPH Cepu); 34,32\%; 43,24\%; 44,97\% (KPH Randublatung); 43,75\%; 37,32\%; $36,60 \%$ (KPH Blora) (BPS, 2006).

Hutan jati bagi keluarga petani miskin pinggiran hutan (desa hutan, desa sekitar hutan) sebagai sumber nafkah (mata pencaharian) guna memenuhi kebutuhan pangan. Dengan pemanfaatan dari pohon jati, seperti daun jati, kepompong/ulat daun jati, belalang, ranting, tunggul, akar kayu jati; atau dari lahan hutan jati, seperti tanaman obat (empon-empon), sayuran, integrasi ternak berizin untuk penggembalaan, atau sumber pakan ternak, tumpangsari (jagung, padi di hutan jati) yang dilakukan oleh pesanggem. Tingginya aksesibilitas nafkah masyarakat sekitar hutan di hutan jati, sehingga memerlukan penataan hubungan sinergis, diantaranya melalui pengelolaan hutan bersama masyarakat (PHBM). PHBM ditetapkan menjadi satu-satunya sistem pengelolaan hutan di wilayah kerja Perum Perhutani ("icon/brand") Kab. Blora, atau Provinsi Jawa Tengah. Pada aspek lain, data BPS dan Bappeda Kabupaten Blora (2006), menunjukkan dominasi luasan hutan jati tidak berkorelasi dengan besarnya sumbangan produk domestik regional bruto (PDRB) yang hanya $15,2 \%$, sedangkan tanaman pangan mencapai $30,5 \%$.

Nafkah keluarga petani miskin di hutan jati Kabupaten Blora guna memenuhi kebutuhan pangan berdasarkan sifat simbiosisnya dapat dibedakan menjadi (a) sifatnya simbiosis mutualisme, yaitu tidak merugikan pihak Perhutani sebagai pengelola hutan; dan (b) sifatnya simbiosis parasitisme, yaitu menimbulkan kerugian di pihak Perhutani. Senada dengan pembagian mencari nafkah tersebut, berdasarkan normanorma yang berlaku, menurut Dharmawan (2001), ada dua jenis strategi nafkah keluarga petani, yaitu (a) normatif, kategori tindakan positif dengan basis kegiatan sosial ekonomi, seperti kegiatan produksi, migrasi, strategi subtitusi, disebut juga "peacefull ways" karena sesuai dengan norma-norma yang berlaku; dan (b) illegal, kategori tindakan negatif yang melanggar hukum, seperti mencuri, membakar pohon jati, disebut juga "non-peacefull ways" karena tidak sesuai dengan norma-norma yang berlaku.

Berdasarkan gambaran di atas, kajian ini mendiskusikan seberapa besar peran hutan jati sebagai sumber nafkah keluarga petani miskin dalam memenuhi kebutuhan pangan, dengan mengambil kasus pada enam desa, yaitu Bodeh, Ngeliron (Kecamatan Randublatung); Bleboh, Nglebur (Kecamatan Jiken); Sumberejo, Ngiyono (Kecamatan Japah). Tujuan dari kajian ini adalah : (1) Melakukan analisis sumber nafkah petani miskin disekitar hutan jati, baik yang sifatnya simbiosis mutualisme maupun simbiosis parasitisme, dan (2) melakukan analisis kerawanan pangan, salah satu dimensi pemenuhan kebtuhan pangan.

\section{METODE PENGKAJIAN}

\section{A. Lokasi dan Waktu}

Luasan hutan jati yang masih dominan di tingkat desa ( $\geq 75$ persen), dan jumlah keluarga petani miskin ( $\geq 24$ persen) sebagai pilihan kajian (purposive), meliputi Desa :

Bodeh, Ngeliron (Kecamatan Randublatung) di KPH Randublatung. Survei dilakukan pada bulan Juli, Oktober, Desember 2007.

Bleboh, Nglebur (Kecamatan Jiken) di KPH Cepu. Survei dilakukan pada April, Juni 2008. Sumberejo, Ngiyono (Kecamatan Japah) di KPH Blora. Survei dilakukan pada bulan September, November 2008.

\section{B. Metode Pengkajian}

Hutan jati bagi keluarga petani miskin desa hutan, desa sekitar hutan sebagai sumber nafkah (mutualisme, parasitisme) untuk memenuhi kebutuhan pangan. Untuk mengukurnya digunakan dua analisis yang saling terkait, yaitu 
sumber nafkah keluarga petani miskin di hutan jati, untuk pemenuhan kebutuhan pangan dengan mengukur tingkat kerawanan, atau ketahanan pangan desa, kecamatan (mengadaptasi Bappeda dan BPS Blora, 2009).

Kajian bersifat cross-sectional, pengambilan data primer diawali dengan pengamatan bersama dalam konteks yang alami (natural setting) (Denzin, and Lincoln, 1994), diskusi kelompok terfokus (focus group discussion, $F G D$ ), dan wawancara mendalam (WM), serta kajian data sekunder. Kajian data primer dilakukan secara berjenjang di tingkat: (a) Kecamatan dengan responden penyuluh, staf $\mathrm{BKPH}, \mathrm{KPH}$, dan dinas pertanian/staf kec (FGD $=6$ responden/kecamatan, dan $\mathrm{WM}=4$ responden/kecamatan); (b) desa dengan responden pengurus lembaga masyarakat desa hutan (LMDH), gabungan kelompok tani (Gapoktan), petani miskin, dan petani perintis/ adopter $((\mathrm{FGD}=10$ responden $/$ desa, dan $\mathrm{WM}=6$ respoden/desa). Kajian data sekunder bersumber dari Badan Pusat Statistik (BPS), Badan Ketahanan Pangan, Dinas Pertanian, Dinas Kehutanan, Dinas Kesehatan Kabupaten Blora, Petugas Statistik dan Cabang Dinas Kecamatan Randublatung, Jiken, dan Japah, serta dari KPH Cepu, Randublatung, Blora.

\section{Pengolahan dan Analisis Data}

\section{Nafkah Keluarga Petani Miskin di Hutan Jati}

Identifikasi, penyusunan hirarki, pengukuran indikator, sub-indikator dan bobot pada analisis sumber nafkah keluarga petani miskin dilakukan peneliti dengan para pakar, mengadaptasi Proses Hirarki Analitik, atau AHP Saaty (1993). Besarnya bobot untuk masingmasing indikator, sub-indikator menunjukan tingkat kepentinganya.

Penilaian sumber nafkah keluarga petani miskin, dengan indikator :

(1) Nafkah yang sifatnya simbiosis mutualisme, terdiri dari:

Y1 : pemanfaatan dari pohon jati, meliputi :Y.1.1. : daun jati di jual ke pasar; Y.1.2. : kepompong/ulat daun jati, belalang; Y.1.3. : ranting, tunggul, akar kayu jati untuk bahan bakar; Y.1.4. : tunggul, akar kayu jati untuk bahan kerajinan;

Y2 : pemanfaatan lahan hutan jati, meliputi : Y.2.1. : empon-empon; Y.2.2. : sayuran; Y.2.3. : integrasi ternak berizin; Y.2.4. : tumpangsari (jagung, padi di hutan jati). SAGA (Socioeccomic and Gender Analisys) diaplikasikan pada nafkah perempuan.

(2) Nafkah yang sifatnya simbiosis parasitisme, terdiri dari : (a) Y3 : pencurian kayu jati, meliputi : Y.3.1. : gangguan akibat pencurian kayu jati, dan dampaknya (Y.3.2.); (b) Y4 : kebakaran hutan jati, meliputi : Y.4.1 : gangguan akibat kebakaran hutan jati, dan dampaknya (Y.4.2.).

Penilaian skor mengacu skala Likert, Semantik differentials, dimana skor $1=$ rendah; 2 = sedang; 3 = tinggi, $4=$ sangat tinggi. Penilaian skor pada indikator, sub-indikator, berdasar-kan kesepakatan peneliti dengan responden. Nilai akhir setiap indikator, sub-indikator adalah bobot (B) $x$ skor $(\mathrm{S})$. Nilai akhir Y1 $=(B Y .1 .1$ x $S)+(B$ Y.1.2.x S) +(B Y.1.3.x S) + (B Y.1.4.x S); dan Y2 $=(B Y .2 .1 \times \mathrm{x})+(\mathrm{B} Y .2 .2 \times \mathrm{x} S)+(\mathrm{B}$ Y.2.3. $\mathrm{x} \mathrm{S})+$ (B Y.2.4.x S).

\section{Pemenuhan Kebutuhan Pangan}

Pemenuhan kebutuhan pangan dari sumber produksi dan kalori utama, yaitu beras, jagung, dan ubi kayu, dengan mengukur indeks komposit tingkat kerawanan, atau ketahanan pangan desa, kecamatan (adaptasi Bappeda dan BPS Blora, 2009), meliputi :

(1)Kerentanan pangan : 1/3 (luas hutan/luas wilayah + luas padi puso/luas panen $+\mathrm{KK}$ terkena dampak banjir/KK total),

(2) Ketersediaan pangan : rasio konsumsi dengan ketersediaan padi, jagung, umbian, meliputi konversi produksi netto (PN) beras (PNB x $0,632 \%)+$ PN jagung $(0,6 * \mathrm{M})+\mathrm{PN}$ ketela pohon $\left(0,6^{*} \mathrm{C}\right)$

(3)Akses pangan dan penghasilan : $1 / 3 \quad(\%$ fasilitas akses pangan $+\%$ RT. Miskin),

(4) Pemanfaatan pangan : 1/4 (\% buta huruf $+\%$ akses puskesmas, air bersih $+\%$ balita gizi kurang/buruk).

Indeks komposit kerawanana pangan $(\mathrm{x})=$ $1 / 4$ indeks $(1+2+3+4)$. Kategori : sangat tahan pangan $(x<0,16)$, tahan pangan $(0,16 \leq x<0,32)$, cukup tahan pangan $(0,32 \leq \mathrm{x}<0,48)$, agak rawan pangan $(0,48 \leq x<0,64)$, rawan pangan $(0,64 \leq x$ $<0,80)$, sangat rawan pangan $(\mathrm{x} \geq 0,80)$, berdasarkan kriteria World Food Programme (WFP) (Bappeda dan BPS Blora, 2009).

Data-data yang terkumpul diedit, tabulasi, dan disusun dalam kelompok, kategorisasi (Bungin, 2003) untuk diintrepretasi dan analisis deskriptif. Uji t (beda nyata) (Steel dan Torrie, 1991), digunakan untuk mengetahui perbedaan antar desa, kecamatan. 


\section{HASIL DAN PEMBAHASAN}

\section{A. Hutan Jati dan Keluarga Miskin}

Kabupaten Blora (Provinsi Jawa Tengah) dengan penguasaan lahan pertanian sempit, tipologi lahan kering, yang cenderung marginal dengan curah hujan rendah (1.268 mm (809 $1.566 \mathrm{~mm}$ ), rataan hari hujan 64 hari (44-74 hari)), merupakan kendala dalam peningkatan pendapatan. Padi dan jagung sebagai komoditas utama untuk memenuhi kebutuhan pangan pokok masyarakat. Populasi ternak sapi dan ayam buras cukup dominan (Lampiran 1), karena masingmasing dimiliki oleh 85 persen dan 100 persen petani. Bagi petani miskin, petani lapisan bawah dan petani gurem, penghasilan dari usahatani atau buruh tani tidak cukup untuk memenuhi kebutuhan hidup sehari-hari.

Keluarga miskin di desa, kecamatan kajian berdasarkan variabel, atau indikator objektif BPS dan Bappeda Kabupaten Blora (2006), meliputi :
(1) kondisi rumah/tempat tinggal, (2) pangan, (3) sandang, (4) kesehatan, (5) aktivitas sosial dan aspek lain cukup tinggi, yaitu 23,82\% $62,82 \%$. Penggunaan kayu bakar untuk memasak dengan pilihan utama bersumber dari hutan jati, dan cukup dominan (96,94\%) (Lampiran 2). Akibat tingginya aksesibilitas masyarakat sekitar hutan terhadap hutan jati tersebut, maka diperlukan penataan hubungan yang sinergis, diantaranya melalui program PHBM PLUS. Keluarga petani miskin di desa-desa kajian menyebar secara merata, berdasarkan 8 indikator bantuan langsung tunai (BLT), mengelompok pada nilai total skor nilai 7 dan 8 . Hasil kategori keparahan kemiskinan, kategori miskin cukup dominan, kemudian diikuti mendekati miskin, dan keluarga sangat miskin (Tabel 1) (BPS, 2006). Rumah tangga sangat miskin adalah buruh tani tidak memiliki rumah, menumpang, sewa, dan tidak memiliki aset berharga (tabungan, emas, TV berwarna, ternak, motor).

Tabel (Table) 1. Kategori keparahan kemiskinan rumahtangga (Category severity of house-hold poverty)

\begin{tabular}{|c|c|c|c|c|c|c|}
\hline \multirow{2}{*}{$\begin{array}{l}\text { Kecamatan (Subdistrict) } \\
\text { Desa (Village) }\end{array}$} & \multirow{2}{*}{$\begin{array}{c}\text { Jumlah } \\
\text { (number) } \\
\text { KK }\end{array}$} & \multirow{2}{*}{$\begin{array}{l}\text { KK } \\
\text { Miskin } \\
\text { (poor) }\end{array}$} & \multicolumn{3}{|c|}{ Kategori RT miskin (Category RT poverty) (\%) } & \multirow{2}{*}{$\begin{array}{c}\text { Total } \\
(\%)\end{array}$} \\
\hline & & & Sangat (very) & $\begin{array}{l}\text { Miskin } \\
\text { (poverty) }\end{array}$ & $\begin{array}{l}\text { Hampir } \\
\text { (almost) }\end{array}$ & \\
\hline Japah & 9.598 & 4.199 & 1,73 & 28,85 & 13,17 & 43,75 \\
\hline Sumberejo & 257 & 131 & 4,60 & 32,75 & 13,79 & 51,14 \\
\hline Ngiyono & 285 & 119 & 0,00 & 34,88 & 6,90 & 41,78 \\
\hline Randublatung & 21.138 & 9.140 & 4,45 & 25,50 & 13,29 & 43,24 \\
\hline Bodeh & 400 & 251 & 2,24 & 58,95 & 1,57 & 62,76 \\
\hline Ngliron & 771 & 314 & 1,54 & 31,37 & 7,68 & 40,59 \\
\hline Jiken & 9.978 & 3.643 & 2,76 & 25,40 & 8,54 & 36,71 \\
\hline Bleboh & 1.458 & 666 & 3,64 & 35,19 & 6,86 & 45,68 \\
\hline Nglebur & 1.304 & 310 & 2,38 & 16,49 & 4,91 & 23,77 \\
\hline
\end{tabular}

Sumber (source) : BPS (2006)

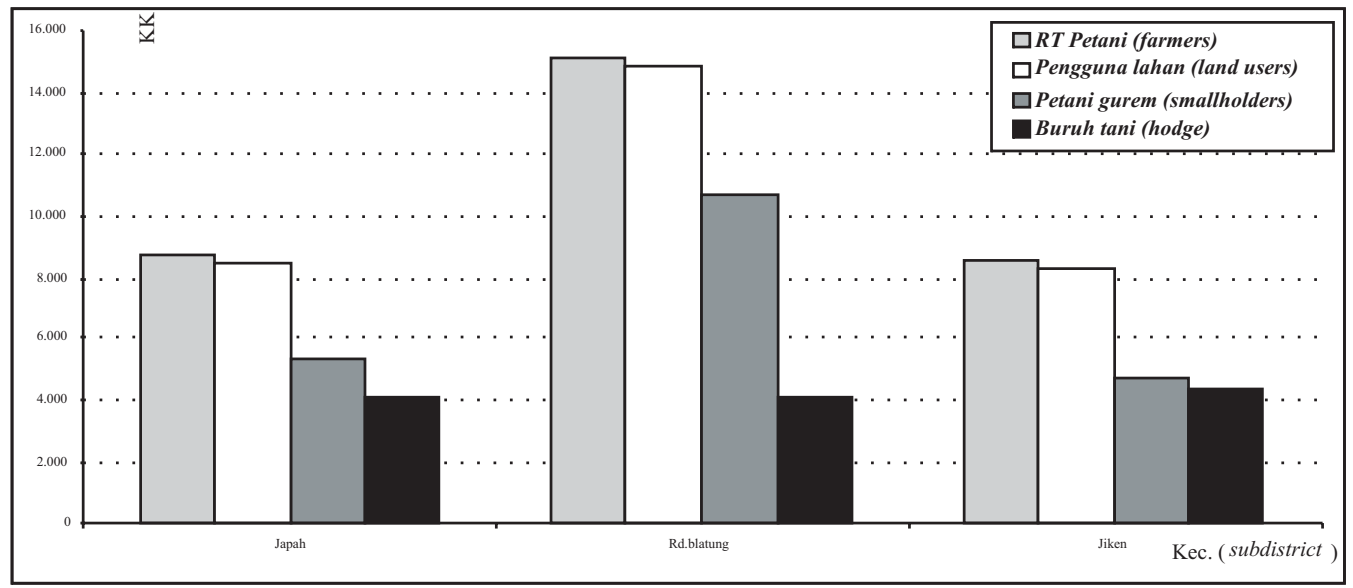

Gambar(Figure) 1. RT petani, pengguna lahan, petani gurem, buruh tani (Farmers househod, land users, landless farmers and farm laborers) 
Keparahan kemiskinan (sangat - hampir miskin) di kecamatan setara, atau lebih tinggi dari jumlah buruh tani hasil Sensus Pertanian 2003, yaitu di Kec. Japah (47,08\%), Jiken $(51,65 \%)$, dan lebih rendah di Randublatung $(27,32 \%)$. Persentasi petani gurem lebih tinggi, di Kec. Japah (63,29\%), Randublatung (71,68\%), Jiken $(57,18 \%)$ (Gambar 1). Persentasi tersebut lebih rendah dari KK pesanggem (petani yang menggarap lahan hutan secara tumpangsari) $(55,24-85,32 \%)$ di desa kajian (Tabel 2). Pada keluarga petani gurem, buruh tani penghasilan dari usahatani dan buruh tidak cukup untuk memenuhi kebutuhan pangan. Untuk itu mereka harus mengalokasikan tenaga kerja ke sektor non pertanian sebagai strategi bertahan hidup (White, 1991 dalam Dharmawan et al., 2004), dan Dharmawan et al., (2004). Dalam kajian ini, sektor non pertanian terfokus pada nafkah, kehidupan (livelihood) di kawasan hutan jati.

Hutan jati memberi kontribusi penyerapan tenaga kerja masyarakat, terutama di pinggiran hutan. Penyerapan tenaga kerja ke hutan jati cenderung berkorelasi dengan luas lahan hutan jati di KPH dan PHBM setempat. Penyerapan tenaga kerja sektor kehutanan yang melibatkan masyarakat desa hutan ada dua, yaitu pekerja harian kehutanan dan jumlah KK pesanggem. Sebagian besar $(67,64 \%)$ sebagai pesanggem $(55,24-85,32 \%)$, dan pekerja harian hanya $23,27 \%$ (kisaran 1,54 - 45\%), selaras penelitian Irhamna (2006), Kuncahyo (2006), di Ghana (Gautman, 2009), Dendi District (Ethiopia) (Mamo et al., 2007), South Africa (Shackleton et al., 2007), dan Vedeld et al. (2007).

Luasan hutan jati di Desa Bodeh $(95,72$ persen), Ngeliron (89,41 persen), dan Kecamatan Randublatung (65,69 persen), Desa Bleboh (77,41 persen), Nglebur (87,84 persen), dan Kec. Jiken (80,01 persen), Desa Sumberejo (80,78 persen), Ngiyono (88,74 persen), dan Kecamatan Japah (54,33 persen) (Lampiran 1). Hutan jati $\mathrm{KPH}$ Randublatung menyebar di Kecamatan Randublatung, Kunduran, Jepon, Banjarejo, Jati, dan Kradenan. Hutan jati KPH Cepu di Kecamatan Jiken, Cepu, Kedungtuban, Sambong, Jepon, dan Banjarejo. Hutan jati KPH Blora di Kecamatan Japah, Todanan, Kunduran, Ngawen, Tunjungan, dan Banjarejo.

Telah terjadi penurunan luas hutan jati produktif pada periode 1996 -2001 dan periode 2002-2006 di Kabupaten Blora. Masing-masing penurunannya sebesar $17,50 \%$ dan $19,89 \%$. Pada periode yang sama, penurunannya di KPH Blora masing-masing sebesar $13,98 \%$ dan $16,76 \%$, di KPH Randublatung 20,12\% dan $24,26 \%$, dan di KPH Cepu penurunanya sebesar $18,41 \%$ dan $18,64 \%$ (Tabel 3).

Tabel (Table) 2. Alokasi tenaga kerja masyarakat desa sekitar hutan di hutan jati (The allocation of labor in rural communities around the forests of teak forests)

\begin{tabular}{|l|c|c|l|c|c|}
\hline $\begin{array}{l}\text { Desa } \\
(\text { village })\end{array}$ & Pesanggem (\%) & $\begin{array}{c}\text { Pekerja (\%) } \\
(\text { workers) }\end{array}$ & $\begin{array}{c}\text { Desa } \\
(\text { village })\end{array}$ & Pesanggem (\%) & $\begin{array}{c}\text { Pekerja (\%) } \\
(\text { workers })\end{array}$ \\
\hline Bleboh & 55,24 & 30,16 & Ngeliron & 60,00 & 35,15 \\
\hline Nglebur & 60,00 & 25,00 & Sumberejo & 85,32 & 1,54 \\
\hline Bodeh & 70,25 & 45,23 & Ngiyono & 75,00 & 2,52 \\
\hline
\end{tabular}

Tabel(Table) 3. Penurunan kelas hutan di KPH Blora, Cepu, Randublatung (Decline forest class in KPH Blora, Cepu, Randublatung)

\begin{tabular}{|l|c|c|c|c|c|c|}
\hline \multirow{2}{*}{ Kelas hutan (Forest class) } & \multicolumn{3}{|c|}{$1996 \mathrm{ke} 2001(\%) \mathrm{KPH}$} & \multicolumn{3}{c|}{$2002 \mathrm{ke} 2006$ (\%) KPH } \\
\cline { 2 - 7 } & Blora & Cepu & Rdblatung & Blora & Cepu & Rdblatung \\
\hline Produktif (productive) & $-13,98$ & $-18,41$ & $-20,12$ & $-16,76$ & $-18,64$ & $-24,26$ \\
\hline $\begin{array}{l}\text { Tidak produktif } \\
\text { (unproductive) }\end{array}$ & $+45,34$ & $+52,96$ & $+176,21$ & $+39,68$ & $+40,16$ & $+126,46$ \\
\hline $\begin{array}{l}\text { Bukan untuk produksi (BUP) } \\
\text { (Not for production) (NFP) }\end{array}$ & $+5,60$ & $+66,52$ & $-2,86$ & $+8,68$ & $+189,42$ & $+4,87$ \\
\hline BUP kayu jati (NFP teak) & $-11,54$ & $-45,12$ & $-32,64$ & $-28,36$ & $-6,87$ & $-29,24$ \\
\hline
\end{tabular}

Sumber/Source : PSDH KPH Cepu (2007) data diolah (processed data) 
Untuk hutan bukan untuk produksi (BUP) kayu jati penurunannya di $\mathrm{KPH}$ Blora masingmasing sebesar $11,54 \%$ dan $28,36 \%$, di $\mathrm{KPH}$ Cepu $45,12 \%$ dan $6,87 \%$, dan KPH Randublatung masing-masing sebesar 32,64\% dan 29,24\%. Sebaliknya terjadi peningkatan hutan tidak produktif dan BUP, senada penelitian Yulianto (2002), Irhamna (2006), dan Kuncahyo (2006). Luas hutan yang menurun cukup besar ini jika tidak ditanggulangi, serta terus berjalan dan dibiarkan saja, maka tinggal menunggu waktu saja sampai sumber daya hutan yang ada akan habis, senada pendapat Appiah (2009) karena semakin menurun hutan produktif, maka supply kayu akan berkurang walaupun permintaan terus bertambah. Hal ini akan berdampak terhadap sumber nafkah petani miskin, seperti kayu bakar, pangan, kayu pertukangan/rumah, empon-empon sebagai bahan obat-obatan.

Penurunan luas hutan jati produktif, BUP kayu jati, dan terjadi peningkatan hutan tidak produktif dan BUP (Tabel 3) selaras dengan rataan peningkatan produksi (ton) padi dan jagung (Gambar 2). Perlu kajian lebih lanjut ada tidaknya korelasinya, karena produksi padi, atau jagung di Kabupaten Blora merupakan resultante produksi di lahan sawah, lahan kering, tumpang sari (dominan jati - jagung, atau jati - padi). Produksi tersebut dipengaruhi faktor-faktor produksi saat budidaya, faktor abiotik, seperti ketersediaan air (iklim), ketersediaan modal petani, dan faktor biotik, seperti serangan hama dan penyakit ekonomis.

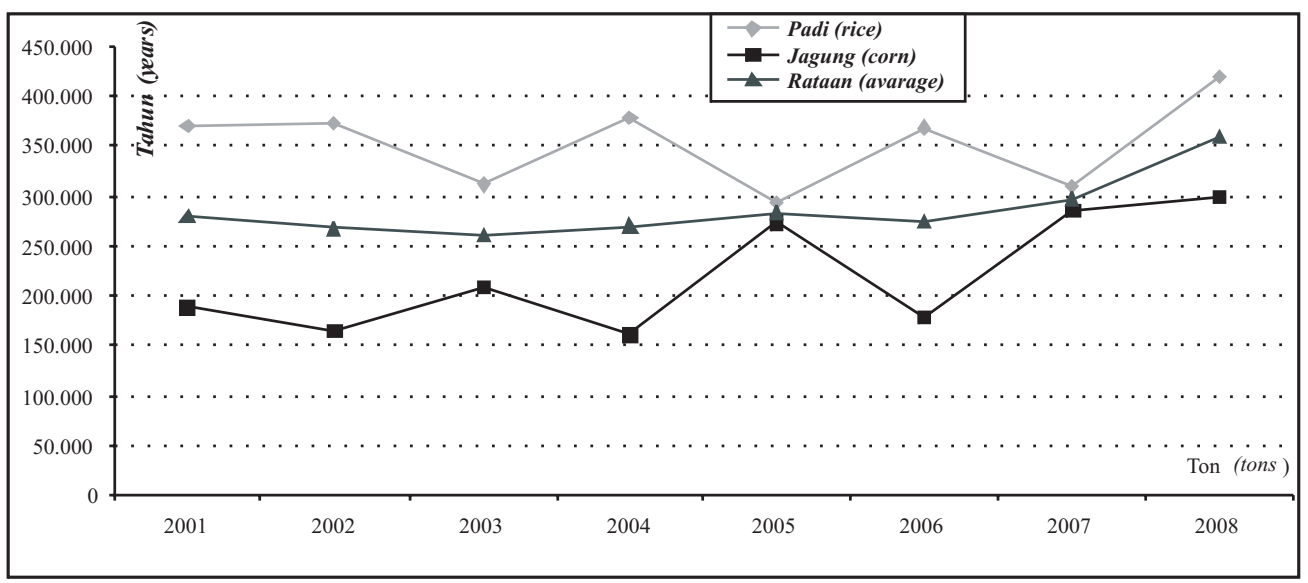

Gambar (Figure) 2. Rataan, produksi (ton) padi dan jagung Kabupaten Blora (Avarage, production (tons) of rice and corn in Blora District (2001-2008))

\section{B. Sumber Nafkah Keluarga Petani Miskin di Hutan Jati}

Berdasarkan kesepakatan peneliti dengan para pakar, nafkah yang sifatnya simbiosis mutualisme (SM) diberi bobot : 0,60 karena memiliki 8 sub-indikator, sedangkan nafkah simbiosis parasitisme (SP) diberi bobot 0,40 karena memiliki 4 sub-indikator.

\section{Nafkah Simbiosis Mutualisme}

Pencarian daun jati untuk dijual ke pasar, tunggul, akar kayu jati untuk bahan kerajinan untuk menambah pendapatan. Pencarian kepompong/ulat daun jati, atau belalang untuk menambah pendapatan, atau langsung dikonsumsi. Pencarian ranting, tunggul, akar, dan rencekan kayu jati sebagian untuk kayu bakar memasak, dan sebagian di jual guna menambah pendapatan. Nafkah yang bersifat simbiosis mutualisme (bobot $=b t=0,60)$, terdiri dari : (a) Y1 $(b t=0,30)$ : pemanfaatan dari pohon jati, dan meliputi : Y.1.1. $(\mathrm{bt}=0,08)$ daun jati; Y.1.2. $(\mathrm{bt}=$ 0,07) kepompong/ulat daun jati, belalang; Y.1.3. $(b t=0,10)$ ranting, tunggul, akar kayu jati untuk bahan bakar; dan Y.1.4. $(\mathrm{bt}=0,05)$ tunggul, akar kayu jati untuk bahan kerajinan; (b) Y2 (bt = $0,30)$ : pemanfaatan lahan hutan jati, meliputi : Y.2.1. (bt $=0,08)$ empon-empon; Y.2.2. ( $b t=$ $0,05)$ sayuran; Y.2.3. $(\mathrm{bt}=0,09)$ integrasi ternak berizin; Y.2.4. $(b t=0,08)$ tumpangsari. Bobot $\mathrm{x}$ skor (nilai akhir) terhadap sumber nafkah yang bersifat simbiosis mutualisme terlihat pada Gambar 3.

Nilai akhir nafkah yang bersifat simbiosis mutualisme (SM) dari pencarian daun jati (Y.1.1) $(0,11)$ merupakan rataan nilai skor $\mathrm{x}$ bobot dari wilayah kajian, yaitu rataan dari : Jiken $(1,90 \times 0,08=0,15)+$ Bleboh $(1,25 \times 0,08=0,10)$ 
+ Nglebur $(1,90 \times 0,08=0,15)+$ Randublatung $(1,25 \times 0,08=0,10)+$ Bodeh $(1,25 \times 0,08=$ $0,10)+$ Ngliron $(1,25 \times 0,08=0,10)+$ Japah $(1,25 \times 0,08=0,10)+$ Sumberejo $(1,25 \times 0,08=$ $0,10)+$ Ngiyono $(1,25 \times 0,08=0,10)$ (Gambar 3). Nilai akhir dari pencarian ranting, tunggul, akar kayu jati untuk bahan bakar (Y.1.3.) memiliki nilai tertinggi $(0,17)$ artinya pemanfaatan kayu jati sebagai bahan bakar untuk memasak dan sebagian di jual cukup dominan (96,94 persen) (Lampiran 2).
Hasil penghitungan subindikator pemanfaatan dari pohon jati (Y1) yang merupakan nilai rataan Y.1.1.; Y.1.2.; Y.1.3; Y.1.4, dengan nilai akhir di Jiken adalah 0,18. Nilai ini merupakan rataan penjumlahan nilai bobot x skor : Y.1.1 $(0,08 \times 1,85)+$ Y.1.2 $(0,07 \mathrm{x}$ $2,15)+$ Y.1.3 $(0,10 \times 2,00)+$ Y.1.4 $(0,05 \times 4,00)$. Sedangkan nilai pemanfaatan dari hutan jati (Y2) $(0,10)$ merupakan Y.2.1 $(0,08 \times 1,50)+Y .2 .2(0,05$ $\mathrm{x} 1,00)+\mathrm{Y} .2 .3(0,09 \times 1,70)+\mathrm{Y} .2 .4(0,08 \times 1,50)$, sehingga nilai nafkah simbiosis mutualisme di Jiken (Y1 + Y2) adalah 0,28 (Tabel 4).

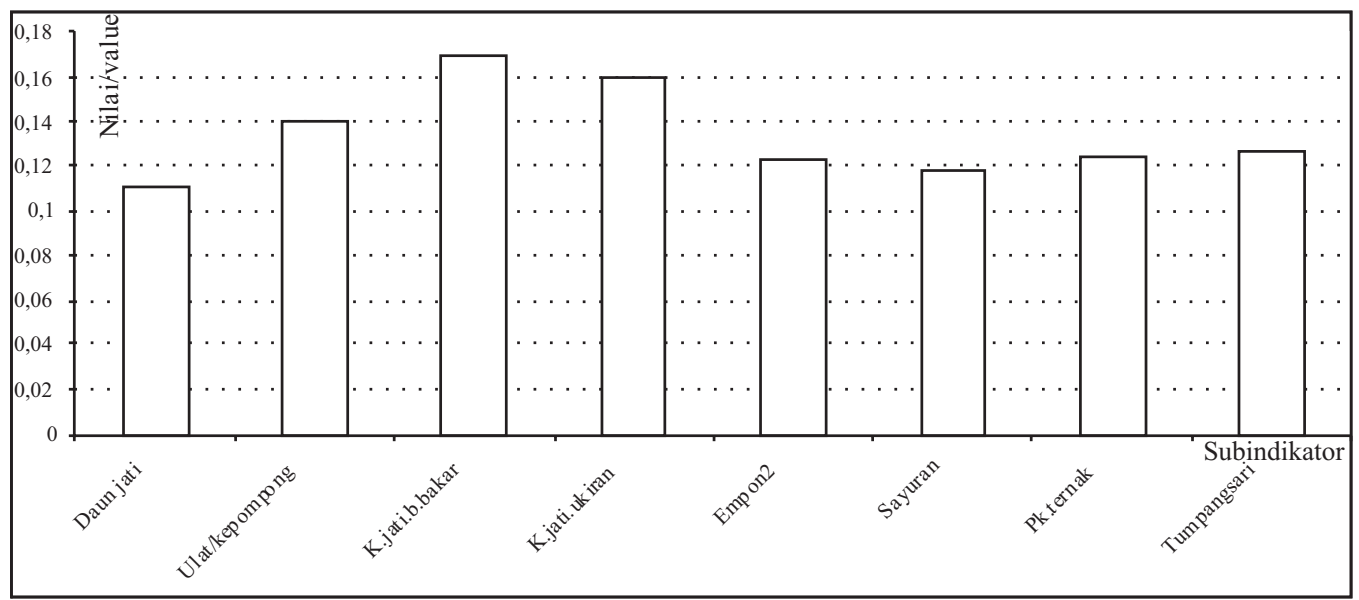

Gambar(Figure) 3. Sumber dan nilai nafkah simbiosis mutualisme (Source and livelihood value from mutualism symbiotic)

Tabel(Table)4. Hasil penilaian nafkah simbiosis mutualisme (The result of symbiosis mutualism livelihood assessment)

\begin{tabular}{|c|c|c|c|c|c|c|c|c|c|}
\hline Indikator & Jiken & Bleboh & Nglebur & Rdblg & Bodeh & Ngliron & Japah & Smbrejo & Ngyno \\
\hline Y.1.1. $(0,08)$ & 0,15 & 0,10 & 0,15 & 0,10 & 0,10 & 0,10 & 0,10 & 0,10 & 0,10 \\
\hline Y.1.2. $(0,07)$ & 0,15 & 0,15 & 0,20 & 0,15 & 0,15 & 0,15 & 0,10 & 0,15 & 0,10 \\
\hline Y.1.3. $(0,10)$ & 0,20 & 0,15 & 0,15 & 0,20 & 0,20 & 0,20 & 0,15 & 0,15 & 0,15 \\
\hline Y.1.4. $(0,05)$ & 0,20 & 0,20 & 0,20 & 0,20 & 0,20 & 0,15 & 0,10 & 0,10 & 0,10 \\
\hline ŷY1 & 0,18 & 0,15 & 0,18 & 0,16 & 0,16 & 0,15 & 0,11 & 0,13 & 0,11 \\
\hline Y.2.1. $(0,08)$ & 0,10 & 0,10 & 0,10 & 0,15 & 0,15 & 0,15 & 0,10 & 0,13 & 0,13 \\
\hline Y.2.2. $(0,05)$ & 0,05 & 0,10 & 0,10 & 0,15 & 0,1 & 0,15 & 0,10 & 0,13 & 0,13 \\
\hline Y.2.3. $(0,09)$ & 0,15 & 0,13 & 0,13 & 0,13 & 0,13 & 0,13 & 0,15 & 0,13 & 0,13 \\
\hline Y.2.4. $(0,08)$ & 0,10 & 0,10 & 0,10 & 0,13 & 0,13 & 0,13 & 0,15 & 0,13 & 0,15 \\
\hline ŷY2 & 0,10 & 0,11 & 0,11 & 0,14 & 0,14 & 0,14 & 0,13 & 0,13 & 0,14 \\
\hline $\mathrm{Y} 1+\mathrm{Y} 2$ & 0,28 & 0,26 & 0,29 & 0,30 & 0,30 & 0,29 & 0,24 & 0,26 & 0,25 \\
\hline
\end{tabular}

Sumber (source) : data primer diolah (primary data processed)

Ket. (note): $\mathrm{Y} 1$ = pemanfaatan dari pohon jati (utilization of teak), Y.1.1.= daun jati (leafteak), Y.1.2. = kepompong/ulat daun jati, belalang (cocoon/teak leaf caterpillars, grasshoppers), Y.1.3 = ranting/tunggul/akar, rencekan kayu jati memasak (branch / stump / root, teak wood rencekan), Y.1.4. = cari tunggul/akar kayu jati untuk kerajinan (search stump/root of teak wood), Y2 = pemanfaatan lahan hutan jati (teak forest land use), Y.2.1. = pencarian empon-empon (searchempon empon), Y.2.2. = pencarian sayuran untuk makan (search vegetables to eat), Y.2.3. = integrasi ternak di hutan jati (integration of livestock in the forests of teak), Y.2.4. = tumpangsari dilahan hutan jati (intercropping in the forests of teak). 
Nilai akhir nafkah simbiosis mutualisme adalah 0,24 - 0,30, nilai tertinggi $(0,30)$ di Desa Bodeh, Kec. Randungblatung, dan terendah $(0,24)$ di Kecamatan Japah. Artinya nafkah simbiosis mutualisme yang dilakukan keluarga petani miskin di hutan jati belum optimal $(0,24$ $0,30)$, karena nilai optimal adalah 0,60 . Hasil uji t antar kecamatan, antar desa tidak berbeda nyata $(\mathrm{p}<0,05)$ (Tabel 4, Gambar 4, Lampiran 3).

Pemanfaatan hutan jati yang belum optimal pada nafkah yang bersifat simbiosis mutualisme tersebut diduga akibat perbedaan rasio sumber nafkah di hutan jati dibanding pemanfaatannya, selaras penelitian di Nepal (Bhattarai et al., 2009; Gautam, 2009); Ghana (Appiah, 2010); Bolivia, Honduras, Nicaragua, Cameroon, Indonesia, Canada (Colchester et al., 2006) Dendi District (Ethiopia) (Mamo et al., 2007), South Africa (Shackleton et al., 2007), dan Vedeld et al. (2007). Perbandingan satuan nafkah yang tersedia diduga lebih kecil dari jumlah pencari nafkah, atau terjadi persaingan (kompetitif) pencari nafkah, misalnya pencari nafkah di Desa Sumberejo tidak terbatas hanya dilakukan oleh pencari nafkah desa tersebut, tetapi dilakukan pencari nafkah desa-desa lain karena potensi, jumlah, satuan sumber nafkah hutan jati pada setiap wilayah BKPH, RPH berbeda-beda, perlu kajian lebih lanjut.

Kawasan hutan jati penghasil emponempon (Gambar 5), seperti lempuyang emprit (wangi), lempuyang pahit (gajah), kunir putih gombyok, sambiroto, kulit kayu (pule dan ragen), pulet, nampu kunci (sayur dan pepet), temutemuan (ireng, lawak, dan giring), jahe emprit + (lengkuas dan asam Jawa) banyak dicari dan sebagai nafkah tambahan terutama dilakukan oleh ibu-ibu atau anak perempuan keluarga petani miskin.

Sumbangan pendapatan berkisar 10\% $15 \%$, selaras menurut Sarjana et al. (2007), Setiani dan Sarjana (2007) dari penambangan lempuyang wangi terhadap pendapatan rumahtangga mencapai 13,56\%. Lempuyang wangi, salah satu komoditas spesifik Kab. Blora yang memiliki keunggulan, baik dari segi peluang pasar maupun potensi sumber daya lahannya. Sentra produksinya tersebar di daerah pedesaan sekitar hutan, dan produksinya masih mengandalkan pengambilan secara langsung dari

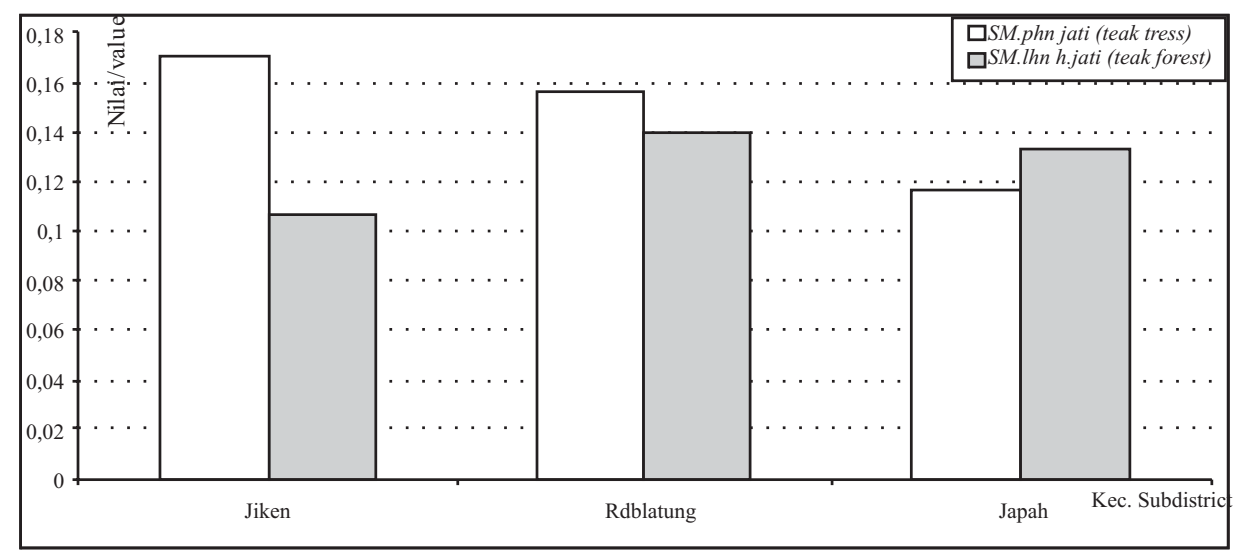

Gambar (Figure) 4. Nilai nafkah dari lahan dan pohon jati (Livelihood value from land and teak trees)
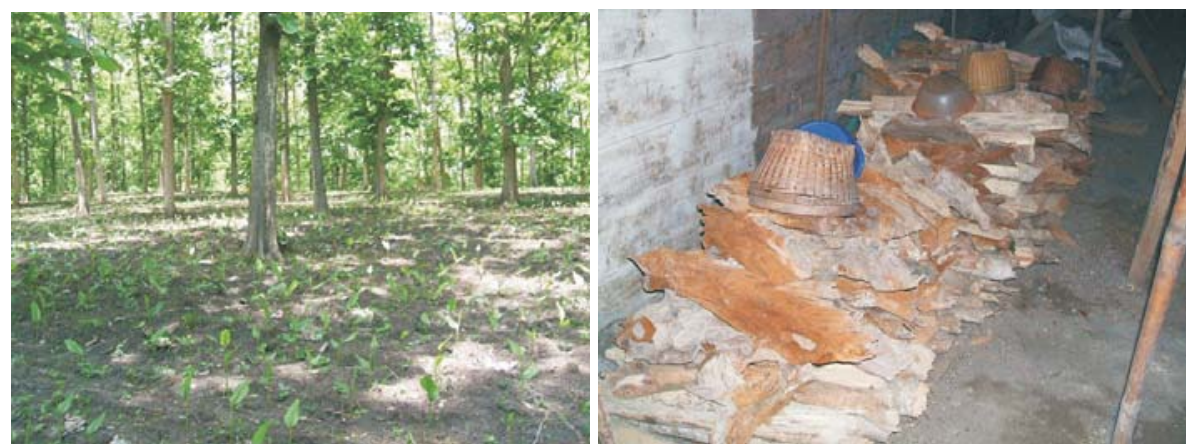

Gambar(Figure) 5. Hutan jati penghasil empon-empon dan kayu bakar (Empon-empon producing teak forests and fire wood) 
hutan jati. Secara umum produksi empon-empon mencapai sekitar 20 - $50 \mathrm{~kg}$ segar, atau sekitar 5 - $10 \mathrm{~kg}$ simplisia kering per orang per hari, selaras penelitian Sarjana et al. (2007), Setiani dan Sarjana (2007). Hal yang sama terjadi pada pencari daun jati untuk dijual ke pasar kecamatan, kabupaten.

Kayu bakar (Gambar 5) merupakan bahan bakar utama keluarga petani miskin cukup dominan (96,94\%) (Lampiran 2), dan hutan jati menjadi pilihan utama sumber konsumsi kayu bakar, selain limbah jagung. Rata-rata konsumsi kayu bakar adalah $62,78 \mathrm{sm} / \mathrm{RT} /$ tahun $(25,67$ 104,44 sm/RT/tahun). Tingginya konsumsi kayu bakar akan menimbulkan masalah tersendiri bagi Perhutani, karena rasio luas lahan tegalan dan sawah dibandingkan luas hutan $(3,5<\mathrm{x}<5,0)$ pemenuhan kayu bakar dari lahan di luar hutan cukup kecil, senada penelitian yang dilakukan Irhamna (2006), Kuncahyo (2006) di Blora, dan peran hutan di Nepal (Bhattarai et al., 2009; Gautam, 2009); Ghana (Appiah, 2010); Bolivia, Honduras, Nicara-gua, Cameroon, Indonesia, Canada (Colchester et al, 2006), Dendi District (Ethiopia) (Mamo et al., 2007), South Africa (Shackleton et al., 2007), dan Vedeld et al. (2007).

Produksi jagung dari lahan hutan jati (Gambar 6) yang dihasilkan oleh pesanggem dari luas lahan sekitar 0,25 ha dengan rata-rata produksi setara beras adalah 0,65 ton/tahun/ RT $(0,34-1,57$ ton/tahun/RT) relatif sangat kecil untuk memenuhi kebutuhan pangan. Tumpang sari tanaman pangan di lahan hutan jati dengan pola tanam usahatani dominan : (1) jagung jagung - bera; (2) padi gogo - jagung - bera; (3) Jagung + ketela pohon - bera, sedangkan tumpang sari tanaman obat (biofarmaka), empon-empon dapat dilakukan sepanjang tahun.
Demplot tumpang sari tanaman sayuran (bayam, kangkung, sawi, mentimun, kacang panjang) di lahan hutan jati umur muda yang bernilai ekonomis dan ramah lingkungan perlu dikaji melalui kerjasama Perhutani, Balai Pengkajian Teknologi Pertanian (BPTP) Jawa Tengah, Dinas Pertanian Kab. Blora. Perlu dukungan Perhutani, Dinas Kehutanan, Dinas Pertanian terhadap sumber air melalui sumur lapang, embung, atau cekdam dari sungai kecil di hutan jati. Pesanggem selama ini paling intensif berinteraksi dengan hutan jati dan mendapatkan banyak manfaat tetapi memiliki daya tawar yang rendah.

Buruh tani yang kemudian menjadi pesanggem dihadapkan pada keadaan tanpa pilihan, karena membiayai gemilangnya keberhasilan tanaman di lahan Perhutani, namun hasil panen yang diterima sebagai upah tidak sebanding dengan dengan tenaga yang dikeluarkan oleh pesanggem, perlu kajian lebih lanjut. Fungsi hutan jati juga sebagai penghasil pakan ternak sangat menguntungkan, tidak terkecuali pesanggem. Besarnya rata-rata kebutuhan pakan ternak setiap keluarga sebesar 232,64 karung/tahun (180,2 - 389,25 karung/ tahun).

Sumber nafkah simbiosis mutualisme berjarak tempuh dari sentra-sentra pemukiman mencapai 3 - $15 \mathrm{~km}$. Mobilitas pencari hasil hutan ini semakin tinggi tidak hanya terbatas di hutan sekitar pemukiman tetapi bisa lintas desa dan kecamatan. Kapasitas produksi setiap pencari hasil hutan sangat bervariasi tergantung kemampuan fisik dalam menggali maupun membawa pulang, serta jumlah yang ditemukan di hutan. Kegiatan nafkah simbiosis mutualisme dengan alokasi waktu bervariasi tergantung jarak tempuh lokasi pencarian.
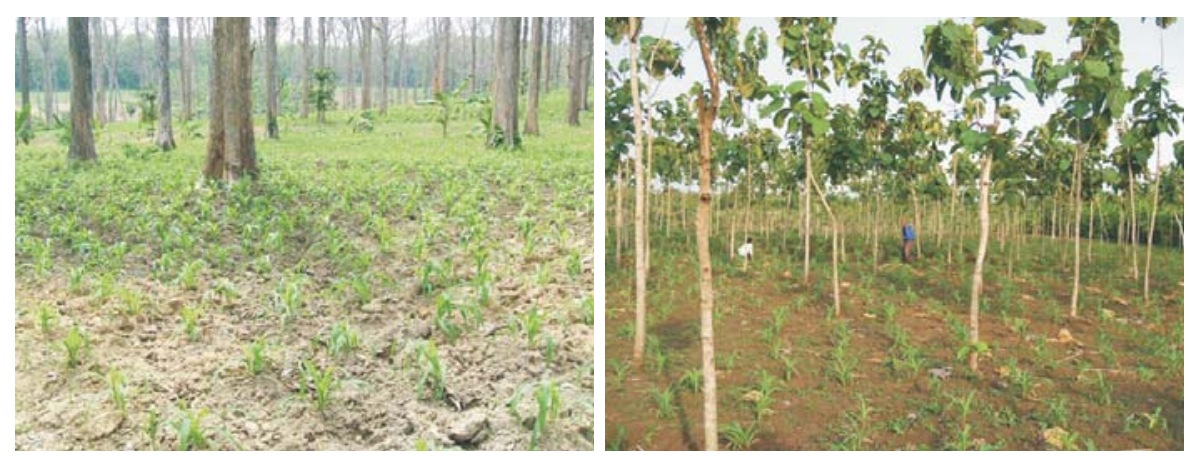

Gambar (Figure) 6. Tumpang sari hutan jati umur tua dan muda - jagung (Teak forest intercropping young and old age-corn) 


\section{Nafkah Perempuan}

Nafkah perempuan di kawasan hutan jati meliputi (a) pencarian empon-empon, (b) pencarian daun jati, (c) pencarian kepompong/ ulat daun jati, atau belalang, (d) pencarian ranting/tunggul/akar dan rencekan kayu jati. Akses perempuan dominan pada a, b, d, dan kegiatan reproduktif, laki-laki pada pencarian tunggul/akar kayu jati. Pencarian kepompong, ulat daun jati, belalang oleh laki-laki, atau perempuan, sehingga alokasi waktu (akses) perempuan di kegiatan produktif pertanian lebih rendah dari laki-laki (Tabel 5).

Peranan produktif adalah peranan yang menghasilkan sesuatu yang bernilai ekonomis (economically actives) (Gambar 7). Peranan perempuan berdasarkan kedudukannya dalam keluarga petani miskin pada kajian ini, sebagai : (1) pencari nafkah, baik tambahan maupun pokok (dominan), (2) istri/ibu rumahtangga (pekerjaan produktif, tidak langsung menghasilkan pendapatan, menunjang anggota lain untuk mencari nafkah); dan (3) anggota masyarakat, selaras (Sayogyo, 1987). Pergeseran dalam peranan antara perempuan dan laki-laki mencerminkan pula perubahan peranan perempuan dalam rumahtangga. Perkembangan dalam organisasi ekonomi yang tradisional, terdapat dua tipe peranan (Sayogyo, 1983; Hubeis, 1993), yaitu : (1) peranan perempuan seluruhnya hanya dalam pekerjaan rumahtangga (peran tradisi), serta (2) perempuan mempunyai dua peranan (peran transisi), yaitu dalam pekerjaan rumahtangga dan perempuan sebagai tenaga kerja, anggota masyarakat dan sumberdaya pembangunan.

Profil aktivitas harian keluarga petani miskin untuk mengetahui kecenderungan, perbandingan pola kegiatan rutin harian individu atau keluarga berdasarkan jender, bukan kodrat. Waktu kerja (akses) antara laki-laki dan perempuan dilahan hutan jati berbeda (Gambar 8), tetapi ada kerjasama bermakna dalam nafkah, juga usaha tambahan antara mereka, memungkinkan peran seluruh keluarga untuk dapat dimanfaatkan dalam nafkah.

Tabel(Table)5. Akses dan kontrol aktivitas harian keluarga miskin (Access and control the daily activities of poor families

\begin{tabular}{|l|c|c|c|c|}
\hline Profil aktivitas produktif (productive activity profile) & \multicolumn{2}{|c|}{ Akses (Acces) } & \multicolumn{2}{|c|}{ Kontrol/control } \\
\hline A. Hutan jati (teak forest) : mencari (to seek) : & $\mathrm{Pd}$ & $\mathrm{Ld}$ & $\mathrm{Pd}$ & $\mathrm{Ld}$ \\
\hline 1. empon-empon & +2 & & $\mathrm{~V}$ & $\mathrm{~V}$ \\
\hline 2. daun jati, kepompong/ulat (teak plant, pupa/worm) & +2 & +1 & $\mathrm{~V}$ & $\mathrm{~V}$ \\
\hline 3. belalang (grasshopper) & +1 & +2 & & $\mathrm{~V}$ \\
\hline 4. ranting dan rencekan kayu jati (twig, rencekan teak) & +1 & +1 & & $\mathrm{~V}$ \\
\hline 5. tunggul atau akar kayu jati (stumps and roots of teak) & & +2 & & $\mathrm{~V}$ \\
\hline B. Pertanian (agriculture) : usahatani, buruh ( ( n farm, labourer) & $\mathrm{Pd}$ & $\mathrm{Ld}$ & $\mathrm{Pd}$ & $\mathrm{Ld}$ \\
\hline 1. padi, jagung, sayuran, ternak sapi (rice, maize, cattle) & +1 & +2 & & $\mathrm{~V}$ \\
\hline 2. kambing/domba, ayam buras (goats, sheep, buras chicken) & +2 & +1 & & $\mathrm{~V}$ \\
\hline
\end{tabular}

Sumber (Source): data primer diolah (primary data is processed)

Keterangan (Note): $\mathrm{Pd}=$ perempuan dewasa (adultfemale),

$\mathrm{Ld}=$ laki-laki dewasa (adult male), akses (access) $:+2=\operatorname{dominan}($ dominant $)$,

$+1=\operatorname{kurang}$ dominan $($ less dominant $), \operatorname{kontrol}($ control $): \mathrm{V}=\operatorname{dominan}($ dominant $)$
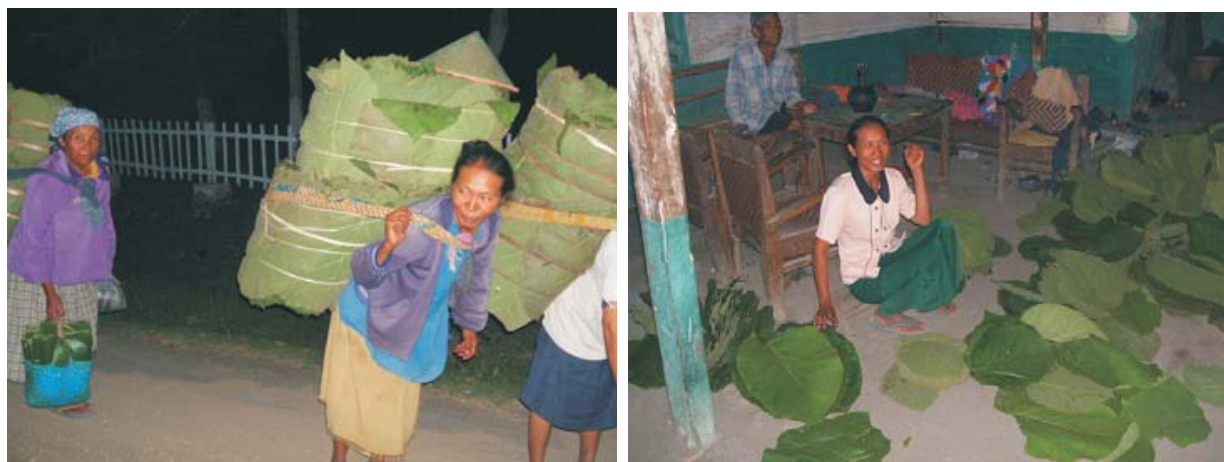

Gambar (Figure) 7. Aktivitas perempuan akan menjual daun jati di pasar Blora (Activities will sell teak leaves women in the market Blora) 
Laki-laki (male farmer)

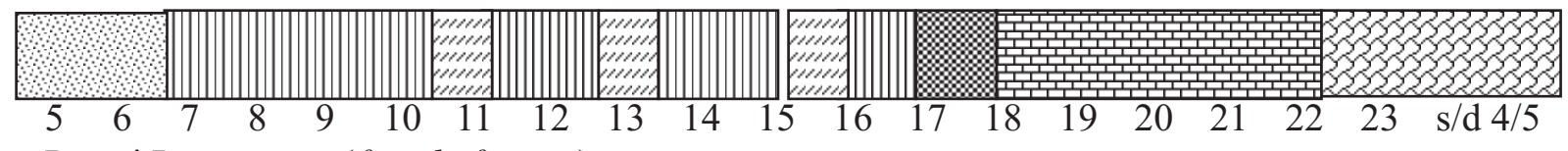

Petani Perempuan (female farmer)

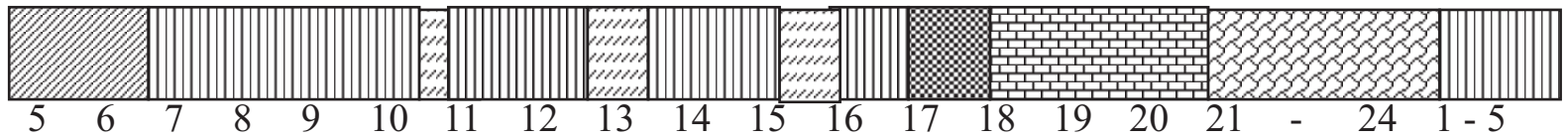

Keterangan (Note):

Bagun pagi, sholat/aktivitas lain, sarapan
Bagun morning prayer / other activities, breakfast
Bagun pagi, sholat, masak, mencuci, urus anak, sarapan
Bagun morning, praying, cooking, washing, child care,
breakfast

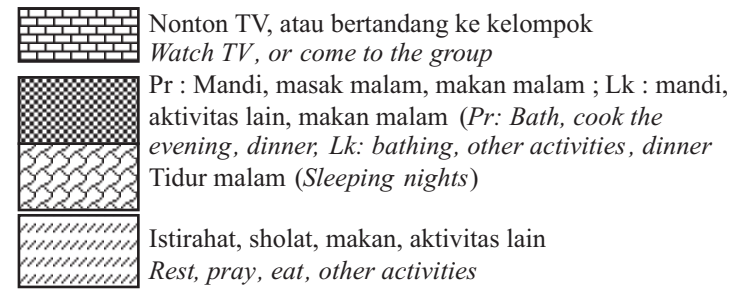

Gambar(Figure) 8. Aktivitas harian keluarga petani miskin (Daily activities poor peasant family)

Tabel(Table)6. Hasil penilaian nafkah simbiosis parasitisme (The result of symbiosis parasitism livelihood assessment)

\begin{tabular}{|c|c|c|c|c|c|c|c|c|c|}
\hline Indikator & Jiken & Bleboh & Nglebur & Rdblg & Bodeh & Ngliron & Japah & Sumbrejo & Ngiyono \\
\hline Y.3.1 $(0,10)$ & 0,20 & 0,20 & 0,20 & 0,10 & 0,10 & 0,10 & 0,10 & 0,10 & 0,10 \\
\hline Y.3.2 $(0,10)$ & 0,40 & 0,40 & 0,40 & 0,30 & 0,30 & 0,30 & 0,30 & 0,30 & 0,30 \\
\hline RtY3 & 0,30 & 0,30 & 0,30 & 0,20 & 0,20 & 0,20 & 0,20 & 0,20 & 0,20 \\
\hline Y.4.1 $(0,10)$ & 0,20 & 0,20 & 0,20 & 0,20 & 0,20 & 0,20 & 0,15 & 0,15 & 0,15 \\
\hline Y.4.2 $(0,10)$ & 0,20 & 0,20 & 0,20 & 0,20 & 0,20 & 0,20 & 0,15 & 0,15 & 0,15 \\
\hline RtY4 & 0,20 & 0,20 & 0,20 & 0,20 & 0,20 & 0,20 & 0,15 & 0,15 & 0,15 \\
\hline Y3+Y4 & 0,50 & 0,50 & 0,50 & 0,40 & 0,40 & 0,40 & 0,35 & 0,35 & 0,35 \\
\hline
\end{tabular}

Sumber (source) : data primer diolah (primary data processed)

Ket. : Y.3.1. = pencurian kayu jati,Y.3.2. = dampaknya; Y.4.1. = kebakaran hutan jati, Y.4.2. = dampaknya

Y.3.1. = theft teak, Y.3.2. = impact; Y.4.1. = teak forest fires, Y.4.2. = impact

Kegiatan nafkah dengan alokasi waktu bervariasi tergantung jarak tempuh lokasi pencarian. Untuk desa-desa yang memiliki kawasan hutan yang relatif masih terpelihara membutuhkan waktu sekitar 3 - 5 jam (berangkat sekitar pukukl 8 pagi, pulang sekitar pukul 1 siang). Sedangkan untuk desa-desa yang populasi di sekitarnya telah punah mencari ke desa atau kecamatan lain, sehingga alokasi waktu yang dibutuhkan dapat mencapai sekitar 9 - 10 jam (berangkat sekitar pukul 7 pagi, pulang sekitar pukul 5 sore), selaras penelitian Sarjana et al. (2007), serta Setiani dan Sarjana (2007), bahkan pencari daun jati untuk menjualnya butuh waktu tambahan 2 - 3 jam (berangkat sekitar pukul 2 pagi, pulang sekitar pukul 5 pagi)
(Gambar 7), pendapatan yang diperoleh sekitar 10.000 - 30.000 rupiah.

\section{Nafkah Simbiosis Parasitisme}

Nafkah yang bersifat simbiosis parasitisme (SP) $(\mathrm{bt}=40)$, terdiri dari : (a) Y3 (bt $=0,20)$ : pencurian kayu jati, meliputi Y.3.1. $(\mathrm{bt}=$ $0,10)$ gangguan akibat pencurian kayu jati, dan dampaknya (Y.3.2.) $(b t=0,10)$; (b) $Y 4(b t=0,20)$ : kebakaran hutan jati, meliputi (Y.4.1.) (bt $=$ $0,10)$ gangguan akibat kebakaran hutan jati, dan dampaknya (Y.4.2.) (bt $=0,10)$. Hasil penghitungan subindikator pencurian kayu jati (Y3) yang merupakan nilai rataan Y.3.1.; Y.3.2.; dengan nilai akhir di Jiken adalah 0,30 . Nilai ini merupakan rataan penjumlahan nilai bobot $\mathrm{x}$ skor : Y.3.1 $(0,10 \times 2,00)+$ Y.3.2 $(0,10 \times 4,00)$. 
Sedangkan hasil penghitungan subindikator kebakaran hutan jati (Y4) $(0,20)$ merupakan Y.4.1 $(0,10 \times 2,00)+$ Y.4.2 $(0,10 \times 2,00)$, sehingga nilai nafkah simbiosis parasitisme di Jiken (Y3 + Y4) adalah 0,50 (Tabel 6, Lampiran 4, 5).

Nilai akhir nafkah yang bersifat simbiosis parasitisme (SP) adalah $0,35 \quad 0,50$, dimana nilai tertinggi $(0,50)$ di Desa Bleboh, Nglebur, dan Kec. Jiken, terendah $(0,35)$ di Desa Sumbe-rejo, Ngiyono, Kecamatan Japah. Artinya nafkah simbiosis parasitisme memiliki rentang merugikan $(0,35)$ sampai sangat merugikan $(0,50)$, karena nilai optimal nafkah ini pada 0,40 (Gambar 9, Lampiran 4). Hasil uji $t$ antar kecamatan, dan antar desa menunjukkan berbeda nyata $(p<0,05)$, terutama di wilayah Jiken.

Pencurian kayu jati sebagai nafkah yang bersifat simbiosis parasitisme sangat merugikan baik dari sisi fisik/material berupa jumlah pohon/tunggak yang hilang/rusak, dan finansial dihitung dengan uang (Tabel 7). Hal senada terjadi di Nepal (Bhattarai et al., 2009; Gautam, 2009), Ghana (Appiah, 2010); Bolivia, Honduras, Nicaragua, Cameroon, Indonesia, Canada (Colchester et al., 2006), Dendi District (Ethiopia) (Mamo et al., 2007), South Africa (Shackleton et al., 2007), dan Vedeld et al. (2007), dibandingkan gangguan hutan lain, seperti kebakaran hutan, perusakan pohon, penggembalaan liar, atau bencana alam di KPH Blora, Cepu, dan Randublatung.

Menurut Yulianto (2002), kerugian material akibat pencurian kayu jati tidak mesti sebanding dengan kerugian finansial, karena perbedaan dalam volume dan kualitas kayu yang akan mempengaruhi taksiran harga kayu curian. Kerugian bersih yang ditanggung Perhutani Unit I Prop. Jawa Tengah di KPH Blora
(Rp.7.067.793.000,-); Cepu (Rp.29.219. 307.000,-), Randublatung (Rp.6.592.985.000,-), dan dari pencurian kayu (A) masih ada yang bisa kembali ke Perhutani, yaitu dalam bentuk kayu sisa pencurian (B), kayu temuan (C), kayu tangkapan (D), dan kayu penggeledahan (E).

Sejak 1997 pencurian kayu menunjukkan peningkatan yang sangat drastis, bahkan setelah bergulirnya era reformasi lebih dikenal dengan istilah "penjarahan hutan" karena betapa parahnya kerusakan yang ditimbulkan akibat terjadinya pencurian kayu secara besar-besaran yang dilakukan masyarakat. Pencurian kayu jati berdasarkan tujuannya dapat dibagi menjadi 3 (tiga) macam, yaitu untuk memenuhi kebutuhan : (1) hidup petani, atau makan seharihari, berupa rencekan, kayu bekas tebangan untuk kayu bakar; (2) keluarga sendiri, untuk keperluan tambal sulam, kerusakan, membangun rumah; dan (3) kebutuhan industri kayu, biasanya melibatkan banyak pekerja, jumlah curian besar, terorganisasi, rutin, berorientasi bisnis, dan ada jaringan yang kompleks. Nafkah simbiosis parasitisme dan gangguan keamanan hutan mengakibatkan terjadi perubahan potensi hutan, baik dari luasan wilayah hutan produktif (Tabel 2), atau potensi tegakan masing-masing kelas umur pohon, berakibat langsung terjadinya banjir besar pada Januari 2002. Dampak lain yang terjadi tahun 1998 - 2001, yaitu dampak sosial, terjadinya ketegangan, rasa tidak aman, tertekan dan ketakutan antara Perum Perhutani dan masyarakat. Terjadi kerawanan sosial karena mendapatkan uang dengan mudah (pencurian), sehingga mudah menghamburhamburkanya (maraknya perjudian, kebiasaan mabuk-mabukan), selaras penelitian Yulianto (2002).

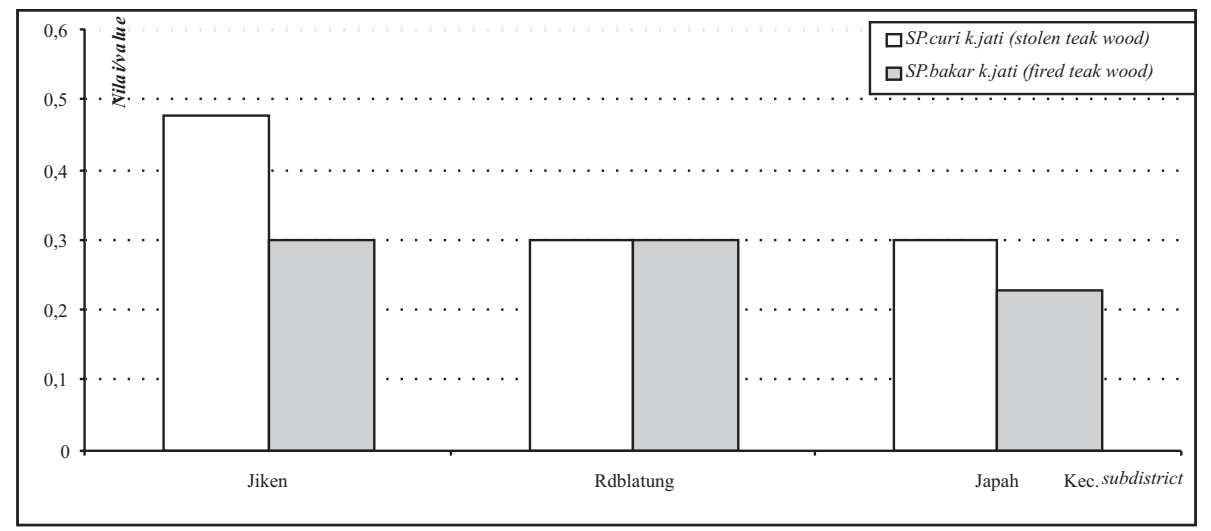

Gambar(Figure) 9. Nilai nafkah dari pencurian atau pembakaran hutan jati (Livelihood value from stolent or fired of teak forest) 
Tabel (Table) 7. Gangguan Keamanan Hutan KPH Blora, Cepu, Randublatung tahun 2000 (Security Disturbance Forest KPH Blora, Cepu, Randublatung in 2000)

\begin{tabular}{|c|c|c|c|c|c|c|}
\hline \multirow{2}{*}{$\begin{array}{l}\text { Gangguan, nilai kerugian } \\
\text { (Disturbance, value loss) }\end{array}$} & \multicolumn{2}{|c|}{ KPH Blora } & \multicolumn{2}{|c|}{ KPH Cepu } & \multicolumn{2}{|c|}{ KPH Rdblatung } \\
\hline & & Rp.1000 & & Rp.1000 & & Rp.1000 \\
\hline $\begin{array}{l}\text { Kebakaran hutan (ha) } \\
\text { (Forest fires (ha)) }\end{array}$ & 47,6 & 7.547 & 276,35 & 42.866 & 152,55 & 897.025 \\
\hline $\begin{array}{l}\text { Perusakan pohon (pohon) } \\
\text { (The destruction of the tree } \\
\text { (tree)) }\end{array}$ & 71.471 & 1.630 .504 & 3.036 & 44.468 & 38 & 28.750 \\
\hline $\begin{array}{l}\text { Penggembalaan liar (ha) } \\
\text { (Wild grazing (ha)) }\end{array}$ & 198,7 & 39.335 & 13,5 & 8.622 & 8 & 60.000 \\
\hline $\begin{array}{l}\text { Bencana alam (pohon) } \\
\text { Natural disasters (tree) }\end{array}$ & 54 & 94.197 & 1 & 2.146 & 19 & 729.650 \\
\hline $\begin{array}{l}\text { Pencurian kayu (pohon)* A } \\
\left.\text { (Theft of wood }(\text { tree })^{*} A\right)\end{array}$ & 48.596 & 12.461 .144 & 80.836 & 41.169 .455 & 38.291 & 20.137 .333 \\
\hline $\begin{array}{l}\text { Kayu sisa pcurian }(\mathrm{m} 3)=\mathrm{B} \\
\text { (Theft of wood rest }(\text { tree })=B \text { ) }\end{array}$ & 6.599 & 4.726 .183 & 14.674 & 8.711 .336 & 13.044 & 6.459 .471 \\
\hline $\begin{array}{l}\text { Kayu temuan }(\mathrm{m} 3)=\mathrm{C} \\
(\text { Wood findings }(\mathrm{m} 3)=C)\end{array}$ & 783 & 542.585 & 5.302 & 3.131 .815 & 700 & 463.836 \\
\hline $\begin{array}{l}\text { Kayu tangkapan }(\mathrm{m} 3)=\mathrm{D} \\
(\text { Wood catchment }(\mathrm{m} 3)=D)\end{array}$ & 146 & 105.227 & 111 & 105.677 & 84 & 157.658 \\
\hline $\begin{array}{l}\text { Kayu geledehan }(\mathrm{m} 3)=\mathrm{E} \\
(\text { Wood raid }(\mathrm{m} 3)=E)\end{array}$ & 27 & 19.356 & 3 & 1.320 & 11 & 3.731 \\
\hline $\begin{array}{l}\text { Kerugian bersih (Net loss) } \\
(\mathrm{A}-(\mathrm{B}+\mathrm{C}+\mathrm{D}+\mathrm{E}))\end{array}$ & & 7.067 .793 & & 29.219 .307 & & 6.592 .985 \\
\hline
\end{tabular}

Sumber (Source): Buku Data Keamanan Hutan KPH Blora, Cepu, Randublatung (2000) diolah, Yulianto (2002)

* = kerugian tunggak (Forest Safety Data Book KPH Blora, Cepu, Randublatung (2000) processed, Yulianto (2002), * =loss stump)

Dampak kerugian yang ditimbulkan sangat besar akibat nafkah simbiosis parasitisme kontradiktif dengan tingkat kesejahteraan masyarakat sekitar hutan daerah kajian, dengan jumlah keluarga miskin cukup tinggi $(23,82 \%$ $62,82 \%$ ). Masyarakat sekitar hutan hanya menikmati keuntungan sekitar 1,20\% - 1,56\%, selaras penelitian ARUPA (1999) di Desa Temulus, KPH Randublatung, yaitu sekitar $1,58 \%$, sisanya $(98,42 \%)$ dinikmati pihak lain di luar masyarakat sekitar hutan (Sanyoto, 2000). Keuntungan yang cukup kecil tersebut tidak akan dapat merubah ketidakberdayaan atau ketidakmampuan memenuhi kebutuhan dasar (basic need), melakukan kegiatan usaha produktif, serta menjangkau akses sumberdaya sosial dan ekonomi. Nafkah ini dilarang pihak Perhutani, dan terjadi persaingan (kompetitif) pencari nafkah dari desa satu dengan desa lain, karena jumlah satuan sumber nafkah pada setiap wilayah berbeda. Kerugian yang besar akibat pencurian kayu juga terjadi di Ghana (Appiah, 2010); Bolivia, Honduras, Nicaragua, Cameroon,
Indonesia, Canada (Colchester et al., 2006), Dendi District (Ethiopia) (Mamo et al., 2007), South Africa (Shackleton et al., 2007), dan Vedeld et al. (2007).

\section{Nafkah keluarga petani miskin}

Nilai penjumlahan (resultante) nafkah keluarga petani miskin di hutan jati (Gambar 10, 11, Lampiran 5, 6, 7) yang merupakan nilai kumulatif nafkah yang sifatnya simbiosis parasitisme (merugikan, konotasi/bersifat negatif) (SP) dengan nafkah mutualisme (tidak merugikan, konotasi/bersifat positif) (SM), sehingga nilai SP + SM di Jiken adalah - 0,50 + $0,28=-0,22$. Nilai $\mathrm{SP}+\mathrm{SM}$ berkisar antara $-0,24$ sampai - 0,09, di Kecamatan Jiken (- 0,22), Desa Bleboh (-0,24), Nglebur (-0,21), artinya nafkah yang sifatnya simbiosis parasitisme sangat dominan dari mutualisme. Resultante di Desa Sumberjo (- 0,09), Bodeh, Ngiyono, Kecamatan Randublatung $(-0,10)$, Desa Ngliron, Kecamatan Japah (- 0,11$)$, artinya nafkah yang sifatnya simbiosis parasitisme kurang dominan dari mutualisme. 


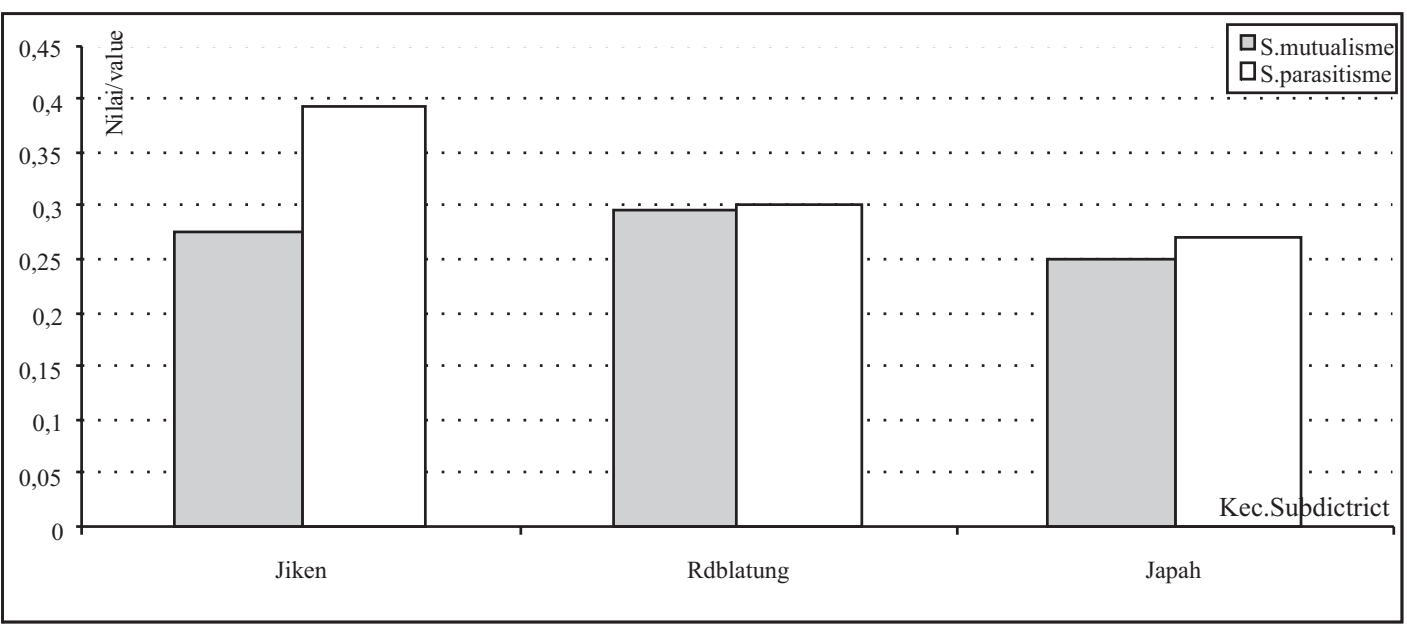

Gambar(Figure) 10. Nilai nafkah simbiosis mutualisme-parasitisme (Livelihood value from mutualism parasitism symbiotic)

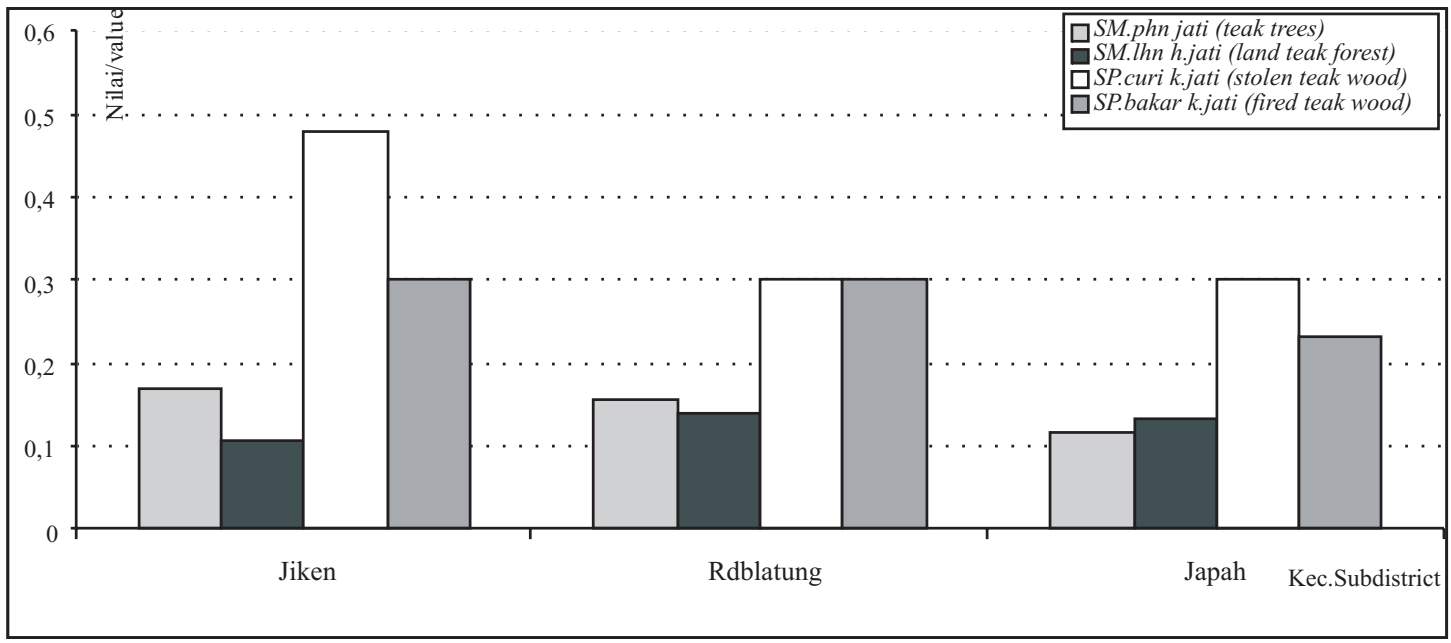

Gambar(Figure) 11. Nilai nafkah subindikator simbiosis mutualisme dan parasitisme (Livelihood value from mutualism and parasitism symbiotic subindicator)

Nilai nafkah yang sifatnya simbiosis mutualisme $(\mathrm{SM})$, meliputi nilai subindikator pemanfaatan dari pohon jati (Y1) dan pemanfaatan dari hutan jati (Y2) memiliki nilai lebih kecil (berbeda nyata, $\mathrm{p}<0,05)($ Gambar 11) dibandingkan nilai nafkah yang bersifat simbiosis parasitisme (SP), yang meliputi pencurian kayu jati dan kebakaran hutan jati.

Nafkah simbiosis mutualisme, parasitisme di hutan jati, serta nafkah di lahan pertanian untuk pemenuhan kebutuhan pangan dan tetap bertahan hidup, secara kumulatif telah dioptimalkan, meliputi : (1) bekerja menambah penghasilan, (2) menjual asset, (3) memanfaatkan bantuan, (4) meminjam atau berhutang, atau (5) usaha lainnya (Tabel 8). Pola nafkah keluarga petani miskin tersebut hanya mampu "mengutamakan selamat" karena kelangkaan, lahan yang sempit, memanfaatkan lahan hutan jati, dan berkat beragam dukungan dari desa, dan "atas desa", meski jumlahnya kecil.

Dukungan pemerintah, berupa bantuan beras (Raskin), BLT; jaring pengaman sosial (JPS) kesehatan (Jamkesmas) dan pendidikan (BOS), bantuan kesehatan (KB murah), beasiswa pendidikan, makanan pendamping ASI (MPASI), makanan tambahan anak balita, anak SD, susu murah, dan pinjaman dana bergulir. Dukungan lain, dari kerabat dan kelembagaan lokal, sumbangan atau pinjaman (tanpa bunga), menggalakkan jimpitan/ perelek beras dan gotong royong. Menurut Manig (1997) dalam Dharmawan (2001), ada dua macam strategi yang dikem-bangkan keluarga petani 
miskin saat kehidupan berada dalam keadaan : (a) normal, dimana nafkah optimal, kebutuhan dasar terpenuhi, dan (b) krisis, dimana kebutuhan dasar tidak terpenuhi. Saat keadaan normal ada 4 strategi yang dikembangkan, yaitu (1) akuisisi, memanfaatkan sumberdaya yang tersedia di alam, (2) alokasi, alokasi sumberdaya (materiil dan immateriil), (3) produksi, mentransformasi materi menjadi bentuk energi lain, dan (4) pemanfaatan jaringan sosial (struktur sosial, membangun jaringan sosial).

Tabel(Table) 8. Strategi nafkah peningkatan pendapatan dan kebutuhan pangan keluarga miskin (Livelihood strategies increase revenues and food needs of poor families)

\begin{tabular}{|c|c|c|c|}
\hline No & Kriteria & Sistem Nafkah & $\%$ \\
\hline 1. & $\begin{array}{l}\text { Bekerja } \\
\text { menambah } \\
\text { pendapatan } \\
\text { (Working to } \\
\text { add revenue) }\end{array}$ & $\begin{array}{l}\text { Menambah jam kerja dan menerima pekerjaan apapun, dan alokasi seluruh } \\
\text { tenaga kerja keluarga (bapak, ibu, anak, lainya) pada : } \\
\text { Adding hours and accept any job, and manpower allocation entire family } \\
\text { (father, mother, child, other) on: } \\
\quad \text { Usaha pertanian (Agricultural business) } \\
\quad \text { Lahan hutan jati (Teak forest land) }\end{array}$ & $\begin{array}{l}35,00 \\
32,00\end{array}$ \\
\hline 2. & $\begin{array}{l}\text { Jual asset } \\
\text { (selling assets) }\end{array}$ & $\begin{array}{l}\text { Menjual atau menggadaikan ternak, barang berharga keluarga } \\
\text { (Sell or pawn livestock, family valuables) }\end{array}$ & 5,00 \\
\hline 3. & $\begin{array}{l}\text { Bantuan } \\
\text { (assistance) }\end{array}$ & $\begin{array}{l}\text { Pemerintah : Raskin, BLT, JPS (kesehatan, pendidikan), dan kera -bat, } \\
\text { tetangga, kelembagaan sosial desa, atau lainnya } \\
\text { (Government: Raskin, BLT, JPS (health, education), and ape-bat, neighbors, } \\
\text { village social institutions, or other) }\end{array}$ & 10,00 \\
\hline 4. & $\begin{array}{l}\text { Berhutang } \\
\text { (Owe) }\end{array}$ & $\begin{array}{l}\text { Meminjam uang/barang ke lembaga formal (koperasi), non formal (kedai, } \\
\text { toko), ke saudara, kerabat, tetangga sekitar } \\
\text { (Borrow money/goods to the formal institutions (cooperatives), non-formal } \\
\text { (shop, store), to siblings, relatives, neighbors) }\end{array}$ & 8,00 \\
\hline 5. & $\begin{array}{l}\text { Lainnya } \\
\text { (Others) }\end{array}$ & $\begin{array}{l}\text { Mencari bahan pangan/non pangan di hutan jati untuk konsumsi, } \\
\text { memanfaatkan tabungan yang dimiliki (barang), atau migrasi sir-kuler ke } \\
\text { kota kabupaten, propinsi, ibu kota } \\
\text { (Finding food/non food in teak forests for consumption, use of savings that } \\
\text { are owned (goods), or migration to the city sircular district, province, } \\
\text { capital city) }\end{array}$ & 10,00 \\
\hline
\end{tabular}

\section{Pemenuhan Kebutuhan Pangan}

Pemenuhan kebutuhan pangan keluarga petani miskin bersumber dari nafkah simbiosis mutualisme dan parasitisme di hutan jati, serta nafkah di lahan pertanian, dengan mengukur indeks komposit tingkat kerawanan, atau ketahanan pangan desa. Indeks komposit merupakan $1 / 4$ dari indeks $(1+2+3+4)$, dimana indeks per indikator : (1) ketersediaan pangan/produksi (Kt.Pangan), (2) akses pangan dan penghasilan (APP), (3) pemanfaatan/ penyerapan pangan (PP), dan (4) kerentanan pangan (Kr.P). Indeks per indikator untuk Desa Sumberejo masing-masing 0,$01 ; 0,23 ; 0,29$; dan 0,32 (Lampiran 8, Tabel 9), dengan indeks komposit adalah $1 / 4(0,01+0,23+0,29+0,32)=$ 0,21 .

Analisis tingkat kerawanan pangan desa, kecamatan (Tabe 9), masalah pangan bukan menjadi hal yang mengkhawatirkan, karena tidak ada desa dan kecamatan kajian masuk kategori rawan pangan, tidak berbeda nyata $(\mathrm{p}<0,05)$ dari indeks komposit $(1+2+3+4)$, sangat tahan pangan $(<0,16)(22,22 \%)$, dan tahan pangan $(0,16 \leq \mathrm{x}<0,32)(77,78 \%)$. Pengukuran dari dimensi : (1) ketersediaan pangan, surplus pangan $(<0,50=$ surplus tinggi $)$ $(100,00 \%),(2)$ akses pangan dan penghasilan, sangat tahan pangan $(<0,16)(22,22 \%)$, tahan pangan $(0,16 \leq \mathrm{x}<0,32)(66,67 \%)$, dan cukup tahan pangan $(0,32 \leq \mathrm{x}<0,48)(11,11 \%)$; (3) pemanfaatan dan penyerapan pangan, sangat tahan pangan $(<0,16)(22,22 \%)$, tahan pangan $(0,16 \leq \mathrm{x}<0,32)(44,45 \%)$, dan cukup tahan pangan $(0,32 \leq \mathrm{x}<0,48)(33,33 \%) ;$ (4) kerentanan pangan, sangat tahan pangan $(<0,16)$ $(66,67 \%)$, dan tahan pangan $(0,16 \leq \mathrm{x}<0,32)$ $(33,33 \%)$. Tingkat ketahanan pangan tersebut dipengaruhi luasan hutan jati pada desa, kecamatan kajian. 
Dimensi ketersediaan pangan, tercatat surplus pangan, artinya kebutuhan akan pangan dapat tercukupi dari hasil produkdi sendiri, sedangkan dimensi akses pangan dan penghasilan masih memprihatinkan pada jumlah rumah tangga miskin yang masih tergolong cukup tinggi $(23,82$ - 62,82\%) (Lampiran 1), tetapi cukup rendah yang belum dapat menikmati akses listrik $( \pm 0,5 \%)$ dan yang masih terisolir dengan kondisi jalan yang kurang memadai $( \pm 3,8 \%)$ (Lampiran 2$)$. Faktor input pertanian, seperti kesuburan lahan dan praktek pengelolaan lahan untuk produksi padi, jagung, dan ubi kayu sebagai indikator ketersediaan pangan. Kecamatan Jiken memiliki daerah pertanian (sawah dan tegalan) hanya $15,40 \%$ dan hutan jati $80,01 \%$, lahan sawah hanya $9,62 \%$ dengan sistem pengairan sebagian $1 / 2$ teknis, sebagian pompa air, tadah hujan. Lahan sawah di desa Bleboh dan Nglebur sangat kecil dibandingkan lahan hutan jati (Lampiran 1). Lahan hutan jati (produksi/reboisasi) di Kecamatan Randublatung $65,69 \%$, pertanian $34,31 \%$ dengan lahan sawah $16,59 \%$, sistem pengairan $1 / 2$ teknis, tadah hujan dan mata air di bukit. Lahan sawah di desa Bodeh dan Ngliron sangat kecil dari lahan hutan jati. Desa Sumberejo dan Ngiyono di Kecamatan Japah memiliki daerah lahan hutan jati cukup dominan, yaitu $80,78 \%$ dan $88,74 \%$, serta kawasan pertanian kecil, yaitu $17,1 \%$ dan $8,78 \%$. Lahan sawahnya hanya $9,32 \%$ dan $4,86 \%$ dengan sistem pengairan tadah hujan dan $1 / 2$ teknis dengan pompa air. Lahan sawah pada desa-desa kajian di Kecamatan Jiken, Randublatung, dan Japah maksimal hanya memiliki IP padi 200. Pada kondisi hari dan curah hujan (mm) per tahun normal, dalam setahun dapat terjadi IP $>300$, pola tanam padi - padi - jagung/kacang tanah (IP 300), atau padi - jagung/kacang sayuran/semangka (IP > 300). Pelaksanaan IP padi 200 belum maksimal didukung bangunan infrastruktur pengairan yang memadai.

Dimensi pemanfaatan dan penyerapan pangan daerah kajian agak mengkhawatirkan, karena masih sekitar 30\% keluarga jauh dari jangkauan Puskesmas (jarak $>5 \mathrm{~km}$ ), walaupun di desa telah berdiri poliklinik desa (polindes), praktek bidan, dan banyak posyandu. Masih banyak keluarga miskin belum menggunakan air bersih sebagai sumber air minumnya, keculai pada desa-desa yang telah dijangkau oleh pembangunan air bersih. Pada dimensi ini masih terdapat status gizi $\mathrm{BB} / \mathrm{TB}$ kurus $( \pm 4,8 \%)$. Untuk dimensi kerentanan pangan, 54,33\% - 88,74\% kecamatan/desa kajian memiliki hutan jati. Tanaman padi mengalami puso dan keluarga mengalami bencana banjir tidak ada kejadian.

Rataan konsumsi pangan tidak berbeda nyata (NS, p < 0,05) antar kecamatan, antar desa kajian, menjadi indikator kebiasaan bertindak dalam pemenuhan kebutuhan pangan, frekwensi makan keluarga miskin, yaitu 15 kali dalam seminggu, atau sekitar 2 - 3 kali dalam sehari, selaras BPS dan Bappeda Blora (2006). Rataan konsumsi beras jagung, jagung, dan ubi kayu/umbi-umbian ada perbedaan $(\mathrm{S}, \mathrm{p}<0,05)$ antar kecamatan, antar desa kajian menjadi indikator belum menjadi kebiasaan bertindak dalam pemenuhan kebutuhan pangan. Rataan konsumsi beras jagung menjadi kebiasaan bertindak masyarakat petani yang berusia tua, tetapi sebagian besar belum menjadi kebiasaan bertindak pada usia muda anak-anak dalam pemenuhan kebutuhan pangan. Konsumsi beras jagung pada petani usia tua pada desa-desa kajian (lahan kering $>$ sawah, produksi jagung $>$ padi, lampiran 1). Beras jagung pada keluarga miskin desa kajian dominan lahan kering, saat kemarau panjang dominan dikonsumsi, dan tidak mempengaruhi aktifitas kerja, atau kesehatan, pola ini telah berjalan puluhan tahun. Diversifikasi pangan dari beras, beras jagung, jagung, dan ubi kayu/umbi-umbian, dan frekwensi makan keluarga miskin saja mencapai 15 kali dalam seminggu, atau sekitar 2 - 3 kali dalam sehari pada masyarakat desa-desa kajian memiliki implikasi terhadap gizi anak balita, dimana kasus status gizi BB/U kurang $( \pm 12,4 \%)$ dan gizi buruk $( \pm 1,6 \%)$, serta status gizi $\mathrm{BB} / \mathrm{TB}$ kurus $( \pm 4,8 \%)$ (Diskes Blora, 2008).

Ada empat kategori utama yang berbeda satu sama lain dalam menilai tindakan sosial masyarakat, selaras penelitian Gunawardani (2002), masyarakat mengkonsumsi beras, beras jagung, dan umbi-umbian, dengan pertimbangan efektif dan efisien, memiliki (a) rasionalitas instrumental (tingkat rasionalitas paling tinggi, meliputi pertimbangan dan pilihan yang sadar yang berhubungan dengan tujuan tindakan dan pertimbangan; (b) rasionalitas yang berorientasi nilai (tipe tindakan yang mengutamakan nilainilai individu yang bersifat absolut, dan tidak jadi masalah jika ternyata nilai akhir malah tidak rasional), (c) tindakan tradisional (tipe tindakan sosial ini non rasional, tanpa refleksi yang sadar atau perencanaan, bertindak sesuai kebiasaan, atau seperti nenek moyang mereka sebelumnya), atau dengan pertimbangan (d) tindakan afektif (tipe tindakan sosial didominasi perasaan, emosi 
tanpa refleksi intelektual, atau perencanaan sadar, tindakan ini benar-benar non rasional, kurang pertimbangan logis, ideologis, dan keriteria rasionalitas lainnya). Secara kuantitatif kajian ini belum kami lakukan, sehingga memerlukan pengkajian lebih lanjut.

\section{KESIMPULAN DAN SARAN TINDAK LANJUT}

\section{A. Kesimpulan}

1. Nafkah simbiosis mutualisme keluarga petani miskin di lahan hutan jati untuk pemenuhan pangan belum optimal $(0,24-0,30)($ optimal $=$ $0,60)$, karena perbedaan rasio sumber nafkah lebih kecil dibandingkan pemanfaatannya. Mobilitas pencarian nafkah tidak hanya terbatas di dalam desa, bisa lintas desa, dan kecamatan, dengan alokasi waktu di atas jam kerja normal (9 - 10 jam), dengan hasil cukup kecil (sekitar 10.000 - 25.000 rupiah/ hari), tidak berbeda nyata antar desa. Pilihan strategi yang dilakukan perempuan pada kondisi eksisting cenderung bukanlah pilihan rasional, tetapi sebagai bentuk respon atas situasi yang menekan.

2. Nafkah simbiosis parasitisme kategori sampai sangat merugikan $(0,35-0,50)$ (optimal $=$ $0,40)$, dan keluarga petani miskin hanya menikmati dalam porsi kecil. Nilai kumulatif nafkah simbiosis parasitisme lebih dominan dari mutualisme, sehingga memiliki nilai akhir berkisar antara - 0,24 sampai - 0,09.

3. Potensi, luasan hutan jati, dan diversifikasi pangan (beras, beras jagung, jagung, dan ubi kayu/jalar) bersinergi terhadap tidak ada desa kajian yang rawan pangan, tetapi sangat tahan pangan $(22,22 \%)$ dan tahan pangan $(77,78 \%)$.

\section{B. Saran Tindak Lanjut}

1. Perlu kajian lanjutan dengan menggunakan analisis regresi berganda, atau analisis jalur, agar diketahui faktor-faktor yang nyata berpengaruh.

2. Kerjasama Perhutani, Balai Pengkajian Teknologi Pertanian (BPTP) Jawa Tengah, Dinas Pertanian Kabupaten Blora dalam introduksi demplot tumpang sari tanaman sayuran (bayam, kangkung, sawi, mentimun, kacang panjang) di areal hutan jati yang bernilai ekonomis tinggi dan ramah lingkungan perlu dikaji.

\section{UCAPAN TERIMA KASI}

Terima kasih kepada : (a) Program Peningkatan Pendapatan Petani Melalui Inovasi (P4MI), Badan Penelitian dan Pengembangan Pertanian, yang telah membiayai kajian saya di Blora pada tahun 2007, 2008; (b) P4MI Kab. Blora dan berbagai pihak lain yang telah membantu kajian di lapangan, sehingga dapat menghasilkan tulisan ini.

\section{DAFTAR PUSTAKA}

Appiah, D.O. 2009. Personifying Sustainable Rural Livelihoods in Forest Fringe Communities in Ghana : A Historic Rhetoric ?. Journal of Food Agriculture \& Environment vol. 7 (3\&4) : 873 - 877.

ARUPA. 1999. Laporan Penelitian Kolaboratif : Penjarahan Hutan di Sekitar Desa Temulus, Randublatung. Tidak dipublikasi.

Bappeda dan BPS (Badan Pusat Statistik) Kabupaten Blora. 2009. Indikator dan Pemetaan Daerah Rawan Pangan Kabupaten Blora Tahun 2009.

Bhattarai, S., P. Kumar Jha. and N. Chapagain. 2009. Pro-Poor Institutions : Creating Exclusi ve Rights to the Poor Groups in Community Forest Management. Journal of Forest and Livelihood 8 (2) August 2009 : $1-15$.

Bungin, Burhan. 2003. Analisis Data Penelitian Kualitatif, Pemahaman Filosofis dan Metodologis ke Arah Penguasaan Model Aplikasi. PT. Raja Grafindo Persada.

BPS (Badan Pusat Statistik) dan Bappeda Kabupaten Blora. 2009. Blora dalam Angka 2008. Kerjasama BPS - Bappeda Kab. Blora. p. 268.

BPS (Badan Pusat Statistik) Kab. Blora. 2003. Profil Pertanian Kabupaten Blora Tahun 2003.

Badan Pusat Statistik Kab. Blora. 2006. Data PSE 05, Bantuan Tunai Langsung (BLT) Blora

BPS (Badan Pusat Statistik) dan Bappeda Kabupaten Blora. 2007. Kecamatan Randublatung, Jiken, Japah dalam Angka 2006. Kerjasama BPS Bappeda Blora. P.69. 
Colchester, M., M. Boscolo., A. ContrerasHermosilla., F. Del Gatta., J. Dempsey., G. Lescuyer., K. Obidzinski., D. Pommier., M. Richards., S.N. Sembiring., L. Tacconi., M.T.V. Rios. and A. Wells. 2006. Justice in the Forest : Rural Livelihoods and Forest Law Enforcement. CIFOR : 1 98.

Denzin., K. Norman. dan Y.S. Lincoln. 1994. Introduction, Entering the Field of Qualitative Research dalam Denzin, Norman K. and Y.S. Lincoln (ed.) 1994. Handbook of Qualitative Research. SAGE Publication.

Diskes (Dinas Kesehatan) Kabupaten Blora. 2008. Angka Gizi Kurang dan Buruk.

Dharmawan A.H. 2001. Farm Household Livelihood Strategies and Socio-economic Change in Rural Indonesia. Disertasi, University of Gottingen, Jerman.

Dharmawan, A.H., B. Krisnamurthi., Suharno., F. Tonny., L.B. Prasetyo., D. Tanjung., L. Fausia., Y. Indaryanti. dan N. W. Prasodjo. 2004. Desentralisasi Pengelolaan dan Sistem Tata Pemerintahan Sumberdaya Alam (Decentralized Natural Resources Management and Govermance System) Daerah Aliran Sungai Citanduy. Project Working Paper Series no. 01. Kerjasama antara Pusat Studi Pembangunan IPB dengan Partnership for Govermance Reform in Indonesia - UNDP. Bogor.

Gautam, A.P. 2009. Equity and Livelihoods in Nepal's Community Forestry. International Journal of Social Forestry (IJSF) 2 (2) 2009: 101 - 122.

Hakim, L. 2008. Penilaian Kerusakan Tegakan Jati dan Kerugian Ekonomi Akibat Kebakaran Hutan (Studi Kasus di KPH Cepu, Perum Perhutani Unit I, Jawa Tengah). Skripsi Departemen Silvikultur, Fak. Kehutanan. Institut Pertanian Bogor. Tidak dipublikasi. p. 48.

Hubeis, A.V.S. 1993. Pembangunan pertanian berwawasan gender. Laporan Khusus no. 4: Pengembangan Terpadu Peranan Perempuan Tani di Provinsi Sumatera Utara. hlm. 47 - 56.

Kuncahyo, B. 2006. .Model Simulasi Pengaturan Hasil Lestari Yang Berbasis Kebutuhan
Masyarakat Desa Hutan. Ringkasan Disertasi Ujian Terbuka, Sekolah Pascasarjana, Institut Pertanian Bogor. Tidak dipublikasi. p. 46.

Kusumawati, I. 2009. Evaluasi Perubahan Kelas Hutan Produktif Tegakan Jati (Tectona grandis L.L.) di KPH Cepu, Perum Perhutani Unit I, Jawa Tengah. Skripsi Departemen Silvikultur, Fak. Kehutanan. Institut Pertanian Bogor. Tidak publikasi.p. 49.

Mamo, G., E. Sjaastad. and Pal Vedeld. 2007. Economic Dependence on Forest Resources : A Case From Dendi District, Ethiopia. Forest Policy and Economic 9 (2007): 916 - 927

Pratiwi, M. R. 2007. Peranan Pengelolaan Sumberdaya Hutan Bersama Masyarakat (PHBM) Dalam Upaya Pengendalian Kebakaran Hutan di KPH Cepu, Perum Perhutani Unit I, Jawa Tengah. Skripsi Departemen Silvikultur, Fak. Kehutanan. Institut Pertanian Bogor. Tidak dipublikasi.p. 10.

RPKH (Rencana Pengaturan Kelestarian Hutan) (Buku 1983 - 1992, 1993 - 2002, 2003 2012) Blora, Cepu, dan Randublatung

Sarjana., I. Ambarsari. dan B. Hartoyo. 2007. Studi Kelembagaan Pemasaran Produk Olahan Lempuyang Wangi di Kabupaten Blora. Prosiding Seminar Inovasi Teknologi Pertanian untuk Pengembangan Agribisnis Industrial Pedesaan di Wilayah Marjinal. Balai Besar Pengkajian dan Pengembangan Teknologi Pertanian. p. $531-539$.

Saaty, T.L. 1993. Pengambilan Keputusan Bagi Para Pemimpin. Proses Hirarki Analitik untuk Pengambilan Keputusan dalam Situasi yang Kompleks. K. Peniwati (Eds.) diter jemahkan oleh L. Setiono dari Decision Making for Leaders. The Analytical Hierarchy Analysis for Decisions in Complex World. PT. Pustaka Binama Pressindo, Jakarta.

Sanyoto, R. 2000. "Notulensi Rakor Kecamatan Randublatung, 12- 6-2000”. Tidak terbitkan

Sayogyo, P. 1983. Peranan perempuan dalam keluarga, rumahtangga dan masyarakat yang lebih luas di pedesaan Jawa. Disertasi, UI. Jakarta. 
Sayogyo, P. 1987. Peranan perempuan dalam perkembangan masyarakat desa. Yayasan Ilmu-ilmu Sosial. Jakarta.

Setiani, C. dan Sarjana. 2007. Kelembagaan Kemitraan Usaha Agroindustri Lempuyang Wangi. Prosiding Seminar Inovasi Teknologi Pertanian untuk Pengembangan Agribisnis Industrial Pedesaan di Wilayah Marjinal. Balai Besar Pengkajian dan Pengembangan Teknologi Pertanian. p. 654- 663.

Shackleton, C.M., S.E. Shackleton., E. Buiten., and N. Bird. 2007. The Importance of Dry Woodlands and Forests in Rural Livelihoods and Poverty Alleviation in South Africa. Forest Policy and Economic 9(2007): 558 - 577.

Steel., G.D. Robert. dan J.H. Torrie. 1991. Prinsip dan Prosedur Statistika, Suatu Pendekatan Biometrik, terjemahan Sumantri, Bambang dari Principles and Procedures of Statistics. 1980. PT Gramedia Pustaka Utama, Jakarta. P. 748.
Wasito. 2004. Aktivitas Harian Petani Berdimensi Jender dan Etnis (Kasus Beberapa Desa di Sumatera Utara). Jurnal Pengkajian dan Pengembangan Teknologi Pertanian, vol. 7, nomor 2, Puslitbang Sosek Pertanian Badan Litbang Pertanian p. $204-213$.

Yantina, S. 2008. Penilaian Dampak Kebakaran Hutan Terhadap Vegetasi di KPH Cepu, Perum Perhutani Unit I, Jawa Tengah. Skripsi Departemen Silvikultur, Fak. Kehutan-an. Institut Pertanian Bogor. Tidak dipublikasi.

Yulianto, Muh. 2002. Analisis Sosial Ekonomi Pencurian Kayu (Studi Kasus Kabupaten Blora Jawa Tengah). Tesis Sekolah Pascasarjana, Institut Pertanian Bogor. Tidak dipublikasi.

Vedeld, P., A. Angelsen., Jan Bojo., E. Sjaastad. and G.K. Berg. 2007. Forest Environmental Incomes and the Rural Poor. Forest Policy and Economic 9 (2007) : 869 - 879 . 


\section{Lampiran (Appendix)}

Tabel (Table) 10. Penggunaan lahan, populasi ternak, dan produksi pangan utama (Use of land, livestock population, and production of major food)

\begin{tabular}{|c|c|c|c|c|c|c|c|c|c|c|c|}
\hline \multirow{2}{*}{$\begin{array}{l}\text { Kecamatan } \\
\text { Subdistrict } \\
\text { Desa } \\
\text { Village }\end{array}$} & \multicolumn{3}{|c|}{$\begin{array}{c}\text { Lahan dominan }(\%) \\
\text { dominant land }(\%)\end{array}$} & \multirow{2}{*}{$\begin{array}{l}\text { R.T } \\
(\%) \\
\text { miskin } \\
\text { (foor) }\end{array}$} & \multicolumn{5}{|c|}{$\begin{array}{c}\text { Produksi empon-empon (ton) } \\
\text { Empon-empon production (tons) }\end{array}$} & \multicolumn{2}{|c|}{$\begin{array}{l}\text { Pangan (ton) food } \\
\text { (tons) }\end{array}$} \\
\hline & $\begin{array}{l}\text { Sawah } \\
\text { Lowland }\end{array}$ & $\begin{array}{l}\text { Tgalan } \\
\text { upland }\end{array}$ & $\begin{array}{l}\text { Hutan } \\
\text { forest }\end{array}$ & & $\begin{array}{l}\text { Lpyan } \\
\text { g }\end{array}$ & Kunir & Kunci & Jahe & Temu2 & $\begin{array}{l}\text { Padi } \\
\text { Rice }\end{array}$ & $\begin{array}{l}\text { Jagung } \\
\text { Corn }\end{array}$ \\
\hline Jiken & 9,62 & 5,78 & 80,01 & 36,52 & 9,20 & 0,80 & 8,40 & 2,55 & 3,70 & 8.085 & 12.842 \\
\hline Bleboh & 7,28 & 9,42 & 77,41 & 45,68 & & & & & & 1.598 & 1.824 \\
\hline Nglebur & 6,58 & 2,82 & 87,84 & 23,82 & & & & & & 1.287 & 1.364 \\
\hline Rdublatung & 16,59 & 9,59 & 65,69 & 43,24 & 23,40 & 2,40 & 13,40 & 4,10 & 12,10 & 26.645 & 36.951 \\
\hline Bodeh & 0,32 & 3,02 & 95,72 & 62,82 & & & & & & 42 & 342 \\
\hline Ngliron & 4,14 & 3,72 & 89,41 & 40,59 & & & & & & 356 & 575 \\
\hline Japah & 20,41 & 19,11 & 54,33 & 43,75 & 18,00 & 9,80 & 21,20 & 4,90 & 6,80 & 18.663 & 16.740 \\
\hline Sumberejo & 9,32 & 7,78 & 80,78 & 51,02 & & & & & & 512 & 842 \\
\hline Ngiyono & 4,86 & 3,92 & 88,74 & 41,78 & & & & & & 224 & 376 \\
\hline
\end{tabular}

Sumber (source) : BPS dan Bappeda Kab. Blora (2006) validasi di lapangan (validation in the field) 2007, 2008

Tabel(Table) 11. Keluarga miskin berdasarkan variabel BPS dan Bappeda Kabupaten Blora (Poor families based on the variable BPS and Bappeda Blora District (2006))

\begin{tabular}{|c|c|c|c|c|c|}
\hline Variabel (variable) & Kriteria (Criteria) & Jiken & Rdtg & Japah & Rataan \\
\hline $\begin{array}{l}\text { Jenis bahan bakar } \\
\text { (Type of fuel) }\end{array}$ & $\begin{array}{l}\text { kayu/bukan minyak tanah } \\
\text { (wood /no kerosene) }\end{array}$ & 99,04 & 93,34 & 98,45 & 96,94 \\
\hline $\begin{array}{l}\text { Konsumsi daging, susu } \\
\text { Consumption of meat, milk }\end{array}$ & tidak pernah (never) & 96,87 & 90,35 & 72,64 & 86,62 \\
\hline $\begin{array}{l}\text { Makan/hari (kali) } \\
\text { meals /day/time }\end{array}$ & $2-3$ kali $(2-3$ times $)$ & 99,58 & 98,60 & 98,90 & 99,03 \\
\hline $\begin{array}{l}\text { Kemampuan berobat (The } \\
\text { ability of medical treatment) }\end{array}$ & mampu (capable) & 88,48 & 62,32 & 83,39 & 78,06 \\
\hline $\begin{array}{l}\text { Pendidikan formal } \\
\text { Formal education }\end{array}$ & «SD/MI & 91,02 & 90,27 & 96,23 & 92,51 \\
\hline $\begin{array}{l}\text { Kepemilikan ternak } \\
\text { Ownership of livestock }\end{array}$ & punya (have) & 42,32 & 33,86 & 57,06 & 44,41 \\
\hline
\end{tabular}

Sumber (Source) : BPS dan Bappeda Blora (2006) validasi di lapangan (validation in the field) 2007, 2008, Keterangan (Note) : Rdtg: Randublatung, 


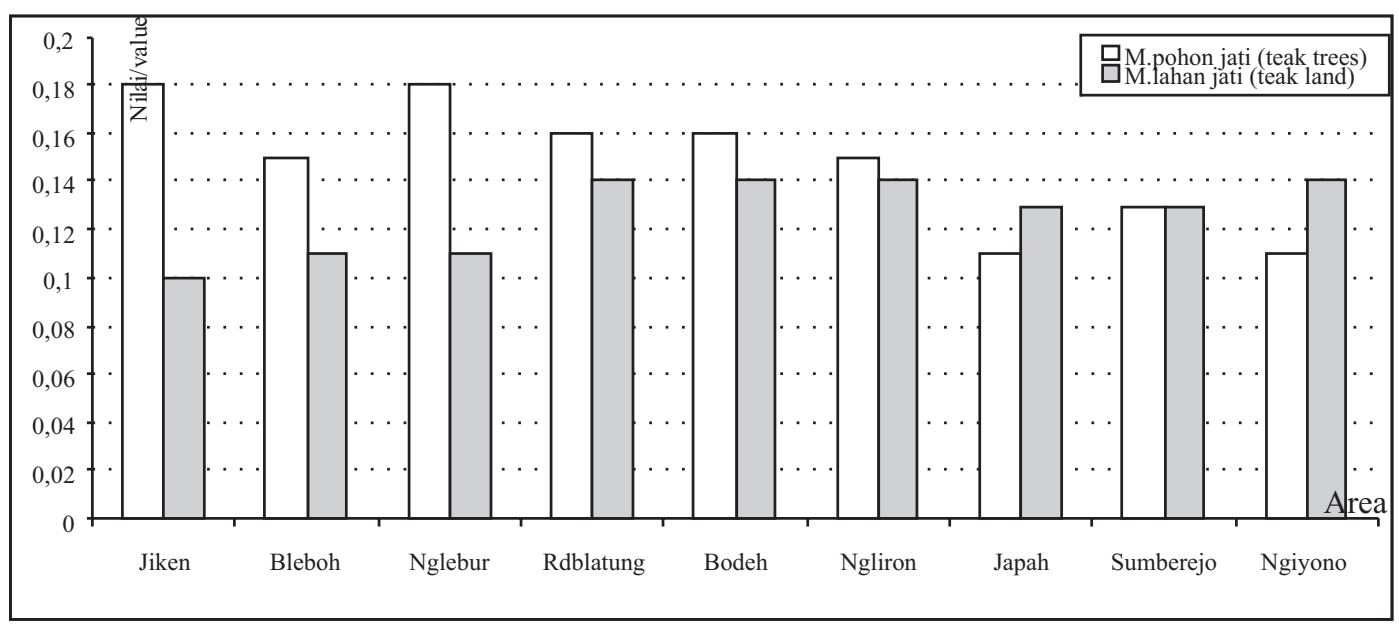

Gambar (Figure) 12. Nilai nafkah dari lahan hutan jati dan pohon jati (Livelihood value from land teak forest and teak trees)

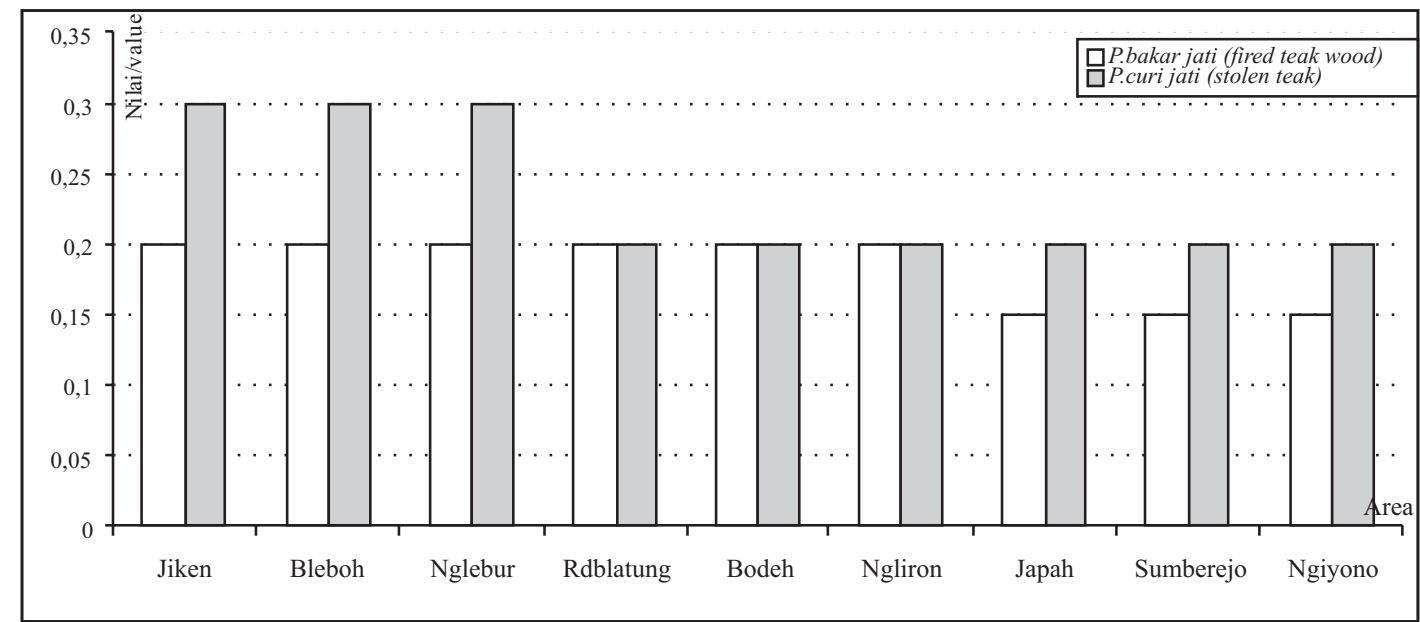

Gambar(Figure) 13. Nilai nafkah dari pencurian, pembakaran hutan jati (Livelihood value from stolen, fired of teakforest)

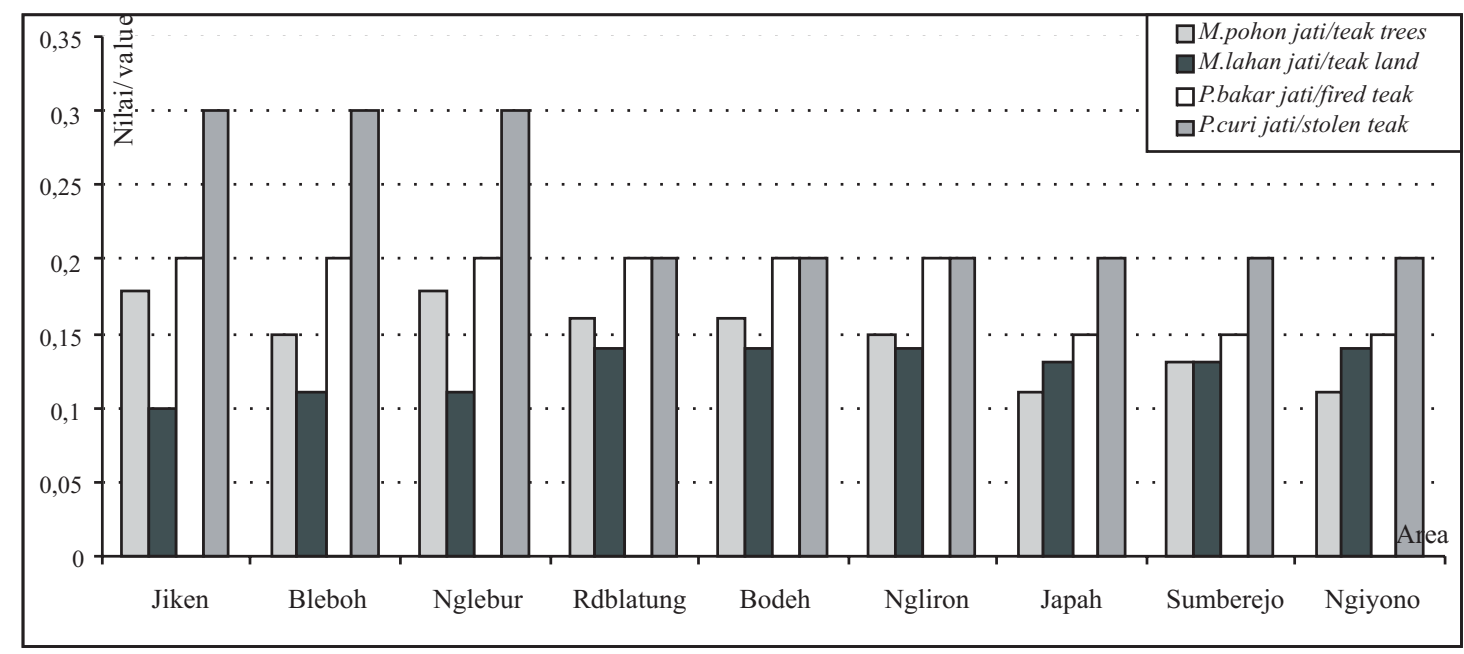

Gambar(Figure) 14. Nilai nafkah dari pohon dan lahan hutan jati, membakar dan mencuri kayu jati (Livelihood value of trees and land teak forest, fired and stolen teak wood) 


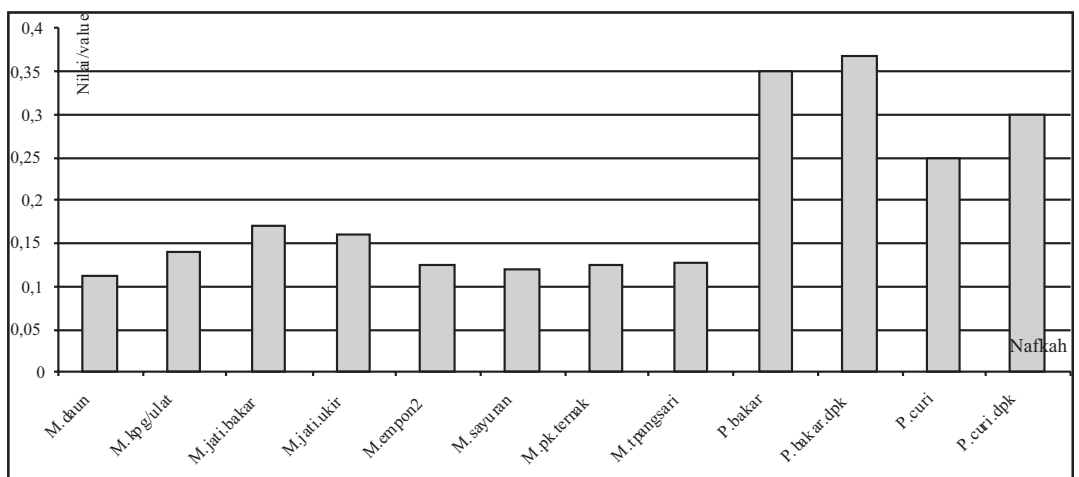

Gambar(Figure) 15. Nilai nafkah subindikator simbiosis mutualisme (M) - parasitisme (P) (Livelihood value from mutualism $(M)$-parasitism $(P)$ symbiotic subindicator)

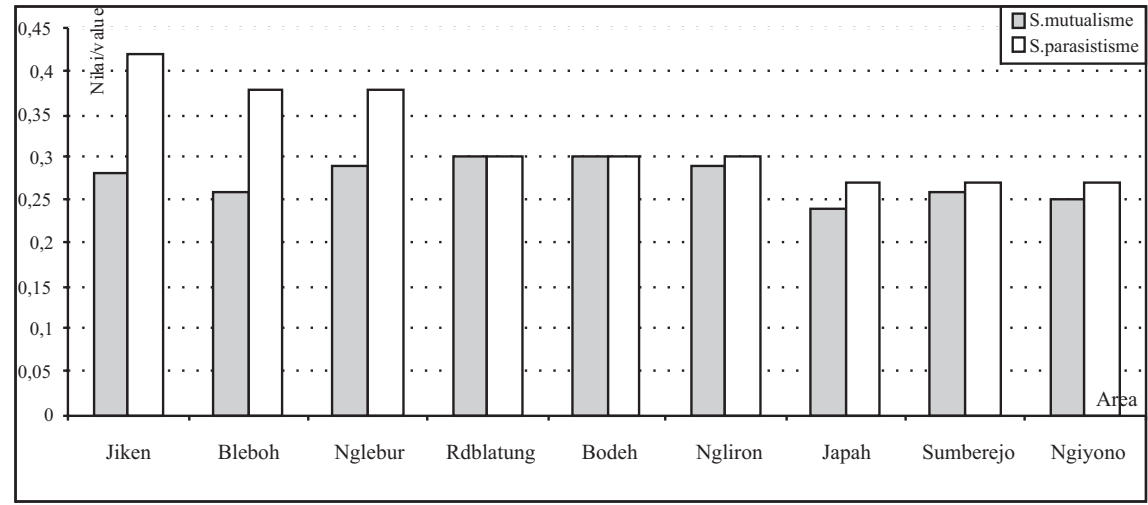

Gambar(Figure) 16. Nilai nafkah simbiosis mutualisme dan parasitisme (Livelihood value from mutualism and parasitism symbiotic)

Tabel(Table) 12. Ketersediaan, akses, kerentanan, dan penyerapan pangan (Food availability, acces, vulnerability, and utilization)

\begin{tabular}{|c|c|c|c|c|c|c|c|c|c|c|}
\hline \multicolumn{11}{|c|}{ A. Ketersediaan pangan (Food availability) } \\
\hline $\begin{array}{l}\text { Kecamatan } \\
\text { Desa }\end{array}$ & \multicolumn{2}{|c|}{\begin{tabular}{l|} 
Produksi \\
Bahan Makan \\
Netto/ton
\end{tabular}} & $\begin{array}{l}\text { Jumlah } \\
\text { pendu duk } \\
\text { (jiwa) }\end{array}$ & \multicolumn{3}{|c|}{$\begin{array}{l}\text { Ketersediaan pa } \\
\text { ngan }(\mathrm{gr} / \mathrm{kpt} / \mathrm{th})\end{array}$} & $\begin{array}{l}\text { Kebutuhan } \\
\text { pang an } \\
\text { (gr/kpt/th) }\end{array}$ & \multicolumn{2}{|c|}{$\begin{array}{l}\text { Indeks=tersedia } \\
: \text { kebutuhan }\end{array}$} & $\begin{array}{c}\text { Indeks } \\
\text { Kt.P }\end{array}$ \\
\hline Japah & \multicolumn{2}{|c|}{33.260} & 33.198 & \multicolumn{3}{|c|}{51.612} & 3.635 & \multicolumn{2}{|r|}{0,07} & 0,12 \\
\hline Sumberejo & \multicolumn{2}{|l|}{735} & 934 & \multicolumn{3}{|c|}{2.156} & 102 & \multicolumn{2}{|r|}{0,05} & 0,01 \\
\hline Ngiyono & 1.104 & \multicolumn{2}{|r|}{994} & \multicolumn{3}{|c|}{3.042} & 109 & \multicolumn{2}{|r|}{0,04} & 0,01 \\
\hline \multicolumn{11}{|c|}{ B. Akses, kerentanan pangan (Food acces, vulnerability) } \\
\hline \multirow{2}{*}{$\begin{array}{l}\text { Kecamatan } \\
\text { Desa }\end{array}$} & \multicolumn{5}{|c|}{ Akses terhadap pangan dan pendapatan } & \multicolumn{5}{|c|}{ Kerentanan pangan } \\
\hline & $\begin{array}{c}* \% \\
\text { pendu-duk } \\
\text { miskin }\end{array}$ & $\begin{array}{c}\% \mathrm{KK} \\
\text { non } \\
\text { listrik }\end{array}$ & $\begin{array}{l}\% \text { jalas } \\
\text { memac }\end{array}$ & & $\begin{array}{l}\text { Indeks } \\
\text { APP }\end{array}$ & $\begin{array}{c}\% \\
\text { luas } \\
\text { hutar } \\
\# \\
\text { \# }\end{array}$ & $\begin{array}{l}\% \text { luas } \\
\text { padi } \\
\text { puso }\end{array}$ & $\begin{array}{l}\% \mathrm{p} \\
\text { korl }\end{array}$ & $\begin{array}{l}\text { enduduk } \\
\text { an banjir }\end{array}$ & $\begin{array}{c}\text { Indeks } \\
\text { Kr.P }\end{array}$ \\
\hline Japah & 43,8 & 0,0 & 15 , & & 0,19 & 54,3 & 0,0 & & 0,0 & 0,21 \\
\hline Sumberejo & 51,1 & 0,0 & 0,0 & & 0,23 & 80,8 & 0,0 & & 0,0 & 0,32 \\
\hline Ngiyono & 41,8 & 0,0 & 0,0 & & 0,18 & 88,7 & 0,0 & & 0,0 & 0,21 \\
\hline \multicolumn{11}{|c|}{ C. Penyerapan pangan (Food utilization) } \\
\hline $\begin{array}{l}\text { Kecamatan } \\
\text { Desa }\end{array}$ & \multicolumn{2}{|c|}{$\begin{array}{c}\text { \% KK jarak ke } \\
\text { Puskesmas » } 5 \text { km }\end{array}$} & \multicolumn{2}{|c|}{$\begin{array}{c}\text { \% KK tanpa } \\
\text { ak-ses air } \\
\text { bersih }\end{array}$} & \multicolumn{2}{|c|}{$\begin{array}{c}\text { \% Perempuan } \\
\text { Buta Huruf }\end{array}$} & \multicolumn{2}{|c|}{$\begin{array}{l}\text { \% Balita Gizi } \\
\text { Kurang/buruk }\end{array}$} & \multicolumn{2}{|c|}{ Indeks PP } \\
\hline Japah & \multicolumn{2}{|c|}{47,5} & \multicolumn{2}{|c|}{0,0} & \multicolumn{2}{|c|}{4,8} & \multicolumn{2}{|c|}{9,9} & \multicolumn{2}{|c|}{0,18} \\
\hline Sumberejo & \multicolumn{2}{|c|}{100,0} & \multicolumn{2}{|l|}{0,0} & & & 10 & & & \\
\hline Ngiyono & 100 & & 0,0 & & & & 9, & & & \\
\hline
\end{tabular}

